\title{
Forchlorfenuron-mimicking haptens: from immunogen design to antibody characterization by hierarchical clustering analysis
}

\author{
Celia Suárez-Pantaleón, ${ }^{a}$ Josep V. Mercader, ${ }^{a}$ Consuelo Agulló, ${ }^{b}$ Antonio Abad-Somovilla, ${ }^{\text {b }}$ Antonio \\ Abad-Fuentes ${ }^{\mathrm{a} *}$
${ }_{5}$ Received (in $\left.X X X, X X X\right) X$ th $X X X X X X X X X 20 X X$, Accepted Xth $X X X X X X X X X 20 X X$ DOI: $10.1039 / \mathrm{b} 000000 x$

To obtain high-specific and selective forchlorfenuron binders, a collection of functionalized derivatives with different spacer arm locations and lengths was prepared. By immunization with target-mimicking haptens, a large battery of monoclonal and polyclonal antibodies against this synthetic cell regulator was 10 produced and exhaustively characterized in two immunoassay formats using homologous and heterologous conjugates. Antibodies with $\mathrm{IC}_{50}$ values lower than $0.3 \mathrm{nM}$ were successfully raised from the prepared immunogens, thus evidencing the efficacy of the explored strategies. In order to identify significant epitopes in the antibody-antigen interaction, a series of new chemical forchlorfenuron analogues, with slight modifications at both rings of the target molecule, were synthesized and evaluated

15 in competitive assays. As a novel approach in hapten recognition studies, data processing was performed by computational classification methods based on hierarchical clustering. This strategy was shown to be highly valuable for a straightforward profiling of antibodies according to analogue recognition patterns. A relationship could be established between the antigen binding properties of antibodies and the structure of the immunogen. Whereas antibodies with equivalent affinities had been obtained from all of the

20 derivatives, their specificity was found to be largely influenced by the differential exposition of the molecule to the immune system.

\section{Introduction}

Small organic molecules need to be covalently coupled to immunogenic carriers in order to obtain antibodies. Therefore,

25 derivatives incorporating a functional chemical group and a spacer arm ought to be synthesized for most substances. A successful production of antibodies mostly relies on the structure of the prepared immunogen, ${ }^{1}$ and hence the immunizing hapten should resemble the target compound almost perfectly. It is well 30 established that a certain immunizing derivative should preserve as much as possible the physicochemical characteristics of the target molecule (steric, electronic, and geometric properties), and therefore the position, composition, and length of the spacer arm are critical aspects in hapten design. ${ }^{2}$ Particularly, the 35 derivatization site within the immunizing hapten, and thus the differential presentation of the immunogen to the immune system, is known to have a strong effect on antibody properties, especially on their specificity. ${ }^{3}$ During the last years, computerassisted molecular modelling techniques have been introduced 40 and structure-activity relationship studies have been carried out to provide useful information with regard to immunogen design. ${ }^{4}$ However, prediction of the structure of the perfect immunizing hapten still remains a challenge. Consequently, for the generation of high-affinity and selective antibodies, it is strongly 45 recommended to prepare an assortment of compounds mimicking the analyte of interest and containing a functional linker at different positions, thus facilitating the presentation of the antigen to the immune system from a variety of perspectives. In addition, heterologous haptens in assay conjugates may contribute to 50 increase the sensitivity of analytical immunoassays.

Forchlorfenuron is a synthetic chloropyridyl phenylurea, also named FCF or CPPU, which has been shown to exert varied biological activities. Structure-activity relationship studies on substituted ureas have revealed that compounds with an intact ${ }_{55} \mathrm{NH}-\mathrm{CO}-\mathrm{NH}$ bridge, a phenyl ring at the $\mathrm{N}$-position, and a substituted heterocyclic ring at the $N^{\prime}$-position significantly enhance cell-promoting function in plants. ${ }^{5}$ In fact, CPPU displays an outstanding phytohormonal activity, ${ }^{6}$ exceeding that of the most active natural and synthetic adenine-substituted ${ }_{60}$ cytokinins, which has markedly determined its notable success as agrochemical. Additionally, CPPU alters, in a specific and reversible manner, the organization of septins, a family of highly conserved GTPase proteins involved in diverse physiological events including cytoskeleton organization, cell division, and 65 morphogenesis in fungi and animals. ${ }^{7}$ These findings have pointed out CPPU as a very valuable candidate to help scientists elucidate the intricate mode of action and function of septins, as well as to increase their knowledge about disorders associated to defects in the regulation of those proteins, like cancer, Parkinson, 70 or Alzheimer diseases.

We have previously described the syntheses of functionalized derivatives with different linker lengths or tethering sites and the 
generation of monoclonal and polyclonal antibodies (mAbs and pAbs, respectively) against CPPU. ${ }^{8}$ In the present study, new haptens have been synthesized to screen novel derivatization positions in the immunizing hapten that may influence the 5 properties of the produced antibodies. In the end, a large library of haptens, conjugates, mAbs, and pAbs for CPPU has been constructed in our lab and it is presented herein. In order to characterize the affinity of the available antibodies and to rationally select the best immunoreagents, competitive enzyme-

10 linked immunosorbent assays (cELISA) in the antibody-coated direct (d-cELISA) format and in the conjugate-coated indirect (i-cELISA) format have been employed. An extensive study was conducted using several heterologous competitors, including conjugates with site, length, and structure heterologies. Next, 15 molecular epitope mapping was carried out by scanning the antibody recognition towards a collection of CPPU-analogous compounds that were specifically designed and synthesized with the aim to establish a correlation between antibody specificity and the structure of the employed immunogen. Moreover, an 20 innovative approach to the study of the binding profiles of the antibodies was applied using an agglomerative hierarchical clustering methodology, which was revealed as a very suitable tool for the analysis of the diversity of a miscellaneous collection of antibodies.

\section{${ }_{25}$ Results and discussion}

\section{Hapten synthesis and conjugate preparation}

Immunogenic conjugates should allow a maximization of the exposition of the main antigenic determinants that are present in the hapten, as they presumably will rule the affinity of the 30 generated antibodies based on their contribution to the molecular forces driving the antibody-antigen interaction. CPPU is a rather symmetric molecule which is comprised of two aromatic systems (phenyl and chloropyridyl rings) linked by a polar urea bridge (Table 1). Concerning the chemical nature of the molecule, the 35 phenyl ring may contribute to hydrophobic interactions with the active site of antibodies, whereas the more polarized 2chloropyridyl group may get involved in electrostatic
Table HChơnical structure of CPPU and synthetic haptens.

\begin{tabular}{|c|c|c|c|c|}
\hline \multirow[b]{2}{*}{ Hapten } & \multicolumn{2}{|c|}{$=\mathrm{N}$} & $\mathrm{R}^{3}$ & \multirow[b]{2}{*}{$X$} \\
\hline & $\mathrm{R}^{1}$ & $\mathrm{R}^{2}$ & $\mathrm{R}^{3}$ & \\
\hline$p 2^{a}$ & $\mathrm{CH}_{2} \mathrm{CO}_{2} \mathrm{H}$ & $\mathrm{H}$ & $\mathrm{Cl}$ & $\mathrm{N}$ \\
\hline p6 & $\left(\mathrm{CH}_{2}\right)_{5} \mathrm{CO}_{2} \mathrm{H}$ & H & $\mathrm{Cl}$ & N \\
\hline CldPhUp6 & $\left(\mathrm{CH}_{2}\right)_{5} \mathrm{CO}_{2} \mathrm{H}$ & $\mathrm{H}$ & $\mathrm{Cl}$ & C \\
\hline PhPyUp6 & $\left(\mathrm{CH}_{2}\right)_{5} \mathrm{CO}_{2} \mathrm{H}$ & $\mathrm{H}$ & $\mathrm{H}$ & $\mathrm{N}$ \\
\hline$m 2$ & $\mathrm{H}$ & $\mathrm{CH}_{2} \mathrm{CO}_{2} \mathrm{H}$ & $\mathrm{Cl}$ & N \\
\hline$m 6$ & H & $\left(\mathrm{CH}_{2}\right)_{5} \mathrm{CO}_{2} \mathrm{H}$ & $\mathrm{Cl}$ & $\mathrm{N}$ \\
\hline s3 & H & H & $\mathrm{S}\left(\mathrm{CH}_{2}\right)_{2} \mathrm{CO}_{2} \mathrm{H}$ & N \\
\hline s5 & H & $\mathrm{H}$ & $\mathrm{S}\left(\mathrm{CH}_{2}\right)_{4} \mathrm{CO}_{2} \mathrm{H}$ & $\mathrm{N}$ \\
\hline $4 \mathrm{Fs} 5$ & $\mathrm{~F}$ & $\mathrm{H}$ & $\mathrm{S}\left(\mathrm{CH}_{2}\right)_{4} \mathrm{CO}_{2} \mathrm{H}$ & $\mathrm{N}$ \\
\hline $4 M s 5$ & $\mathrm{Me}$ & $\mathrm{H}$ & $\mathrm{S}\left(\mathrm{CH}_{2}\right)_{4} \mathrm{CO}_{2} \mathrm{H}$ & $\mathrm{N}$ \\
\hline
\end{tabular}

interactions. Additionally, the azomethynic nitrogen atom in the pyridyl ring and the ureido group make possible the formation of 40 hydrogen bonds. Having all those considerations in mind, functionalized derivatives of CPPU with different derivatization sites and linker lengths were designed (Table 1). The ureido bridge was maintained intact in all of the derivatives, given the relevant participation generally attributed to this moiety in the 45 molecular recognition towards phenylurea compounds. ${ }^{9}$ Immunizing haptens were prepared with the spacer arm located at the phenyl ring, more precisely, at the para and the meta positions ( $p$-type and $m$-type haptens, respectively), and at the C-2 position of the pyridyl ring through substitution of the 50 chlorine atom by a thioalkyl chain (s-type haptens). The nucleophilic substitution of a chlorine atom by a carboxyalkylthiol group in immunizing haptens has been successfully employed before by other authors for the production of antibodies against molecules containing this halogen. ${ }^{3 a, 10}$

A)
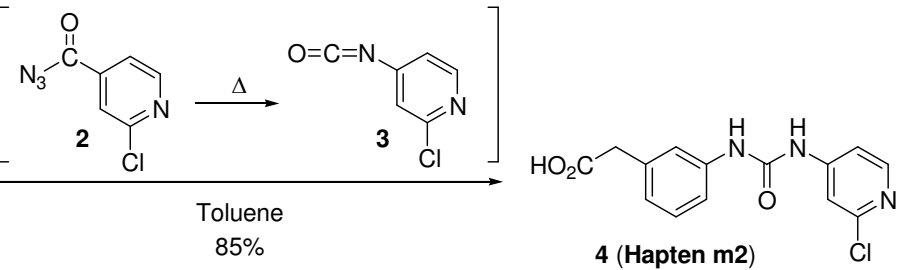

B)
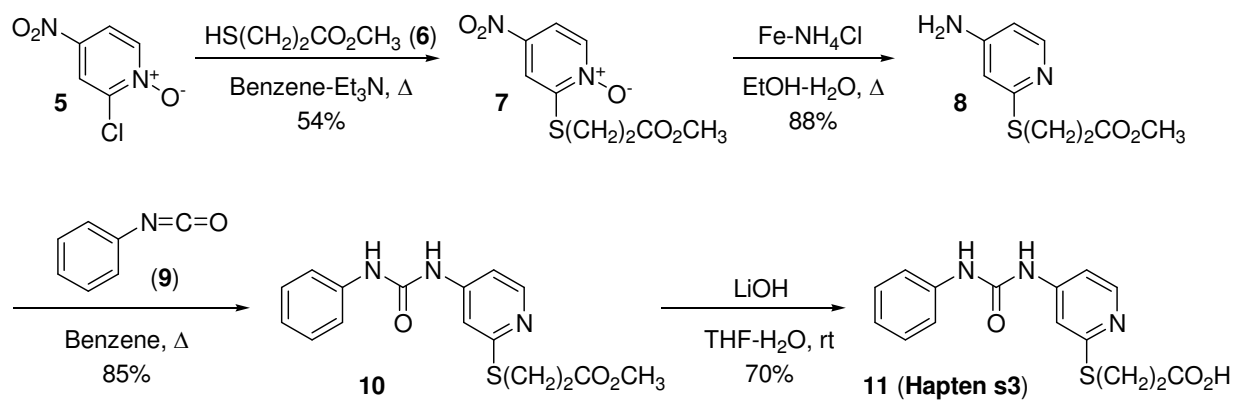

Scheme 1 Preparation of immunizing haptens $m 2$ and $s 3$ 
For the preparation of new immunizing and assay competitor haptens $(m 2, s 3,4 \mathrm{~F} s 5$, and $4 \mathrm{M} s 5)$, we followed the general synthetic approach commonly used for this type of compounds, which is based on the formation of the ureido moiety via reaction 5 of a conveniently functionalized aryl- or pyridyl-amine with the appropriate isocyanate. Thus, hapten $m 2$ (4, Scheme 1A) was efficiently obtained by reaction of commercially available 2-(3aminophenyl)acetic acid (1) with 2-chloro-4-isocyanatopyridine (3), which was prepared in situ, due to its high instability, in a 10 one-pot reaction by Curtius rearrangement of 2-chloroisonicotinoyl azide (2). ${ }^{8}$ On the other hand, the synthesis of hapten $s 3(\mathbf{1 1}$, Scheme 1B) required the previous preparation of the aminopyridine $\mathbf{8}$, which was initiated by the reaction of 2 chloro-4-nitropyridine $N$-oxide $(\mathbf{5})^{12}$ with commercially available 15 methyl 3-mercaptopropanoate (6) in the presence of $\mathrm{Et}_{3} \mathrm{~N}$ as basic catalyst at reflux of benzene. ${ }^{11}$ The nucleophilic aromatic substitution reaction of the chlorine atom by the methoxyoxopropylthiol group to give compound 7 took place with moderate yield (54\%) due, at least in part, to the competitive 20 substitution reaction of the C-4 nitro group. Simultaneous reduction of the nitro and $\mathrm{N}$-oxide moieties of this product with metallic iron afforded the required aminopyridine 8. Finally, the synthesis of hapten $s 3$ was readily completed in high yield by reaction of $\mathbf{8}$ with phenyl isocyanate followed by basic hydrolysis 25 of the ester moiety of the initially formed methyl ester $\mathbf{1 0}$. The synthesis of assay competitor haptens (4Fs5 and 4Ms5) was effected in a similar way by reaction of methyl 5-((4aminopyridin-2-yl)thio)pentanoate ${ }^{8 \mathrm{~b}}$ with 4-fluoroisocyanatobenzene and 1-isocyanato-4-methylbenzene, respectively, as 30 described in the $\mathrm{ESI} \dagger$ (Scheme S1).

Haptens were activated and coupled to bovine serum albumin (BSA) by the active ester method, and to ovalbumin (OVA) and horseradish peroxidase (HRP) by the mixted anhydride method to afford the immunogens and assay conjugates, respectively (see 35 the ESI $\uparrow$ ). Coupling of hapten $s 3$ to OVA and HRP by the mixed anhydride method resulted in a poorly recognized conjugate.

Table 2 Influence of heterologous conjugates on antibody $I_{50}$ values $(n M)^{a}$.

\begin{tabular}{|c|c|c|c|c|c|c|c|c|c|c|c|c|c|c|c|c|c|c|c|c|c|}
\hline \multirow[b]{3}{*}{$A b^{b}$} & \multicolumn{10}{|c|}{ i-cELISA } & \multicolumn{11}{|c|}{ d-cELISA } \\
\hline & \multicolumn{10}{|c|}{ OVA conjugate } & \multicolumn{11}{|c|}{ Enzyme tracer } \\
\hline & $\approx$ & 8 & $\begin{array}{l}\frac{8}{2} \\
\frac{1}{2} \\
\frac{0}{0}\end{array}$ & $\begin{array}{l}\frac{8}{2} \\
\frac{1}{2} \\
\frac{1}{2} \\
\frac{c}{2}\end{array}$ & हี & है & ஜ & せ & $\begin{array}{l}\stackrel{\mathscr{W}}{\mathscr{\psi}} \\
\stackrel{\leftarrow}{+}\end{array}$ & $\sum_{\forall}^{\mathscr{L}}$ & $\mathrm{Ab}$ & $\approx$ & $\notin$ & $\begin{array}{l}\frac{8}{2} \\
\frac{1}{\frac{1}{0}} \\
\frac{0}{0}\end{array}$ & 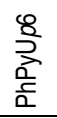 & है & है & ஜ & ڤ & $\begin{array}{l}\stackrel{\mathscr{W}}{\mathscr{\psi}} \\
\stackrel{4}{+}\end{array}$ & $\sum_{\forall}^{\infty}$ \\
\hline p2\#52 & 0.48 & 0.43 & 0.35 & & 0.31 & 0.31 & 0.34 & 0.17 & 0.24 & 0.19 & p2\#52 & 0.83 & 4.48 & 0.72 & & 0.98 & 4.35 & & 1.06 & 1.07 & 1.22 \\
\hline p2\#61 & 0.21 & 0.14 & 1.31 & & 0.18 & 0.31 & 0.10 & 0.07 & 0.07 & 0.66 & p2\#61 & & 0.44 & & & & 0.23 & & & & \\
\hline p2\#65 & 0.42 & 0.22 & 2.87 & & 0.21 & 0.52 & 0.22 & 0.12 & 0.18 & 0.17 & p2\#65 & 0.24 & 1.00 & 0.27 & & 0.24 & 0.65 & & 0.31 & 0.26 & 0.31 \\
\hline p2\#66 & 0.33 & 0.47 & & & 0.37 & 0.37 & 0.51 & 0.20 & 0.28 & 0.33 & p2\#66 & 0.29 & 0.57 & & & 0.18 & 0.44 & & 0.21 & 0.23 & 0.22 \\
\hline p6\#24 & 0.33 & 0.20 & 0.38 & & 0.21 & 0.24 & 0.23 & 0.17 & 0.18 & 0.15 & p6\#24 & & 0.61 & 0.41 & & & 0.79 & & 0.21 & 0.19 & \\
\hline p6\#33 & 2.42 & 0.38 & & & 0.37 & 0.42 & 0.47 & 0.39 & 1.10 & 0.46 & p6\#33 & 0.79 & 1.53 & & & 0.68 & 4.06 & & 0.50 & 0.43 & 0.55 \\
\hline p6\#41 & 0.31 & 0.45 & 0.61 & & 0.14 & 0.23 & 0.15 & 0.23 & 0.20 & & p6\#41 & & 0.33 & & & & & & & & \\
\hline p6\#42 & 0.12 & 0.13 & 0.22 & & 0.16 & 0.13 & 0.07 & 0.09 & 0.08 & 0.25 & p6\#42 & 0.42 & 0.60 & 0.53 & & 0.37 & 0.67 & & 0.28 & 0.40 & 0.25 \\
\hline Rp6\#1 & 1.36 & 0.49 & 0.42 & 1.14 & 0.80 & 0.55 & 0.27 & 0.30 & 0.31 & 0.67 & Rp6\#1 & 0.87 & 0.89 & 1.12 & & 0.58 & 0.71 & & 0.42 & 0.35 & 0.77 \\
\hline Rp6\#2 & 4.82 & 0.76 & 0.37 & 0.31 & 1.54 & 2.25 & 0.42 & 0.89 & 1.53 & 1.07 & Rp6\#2 & 1.02 & 2.11 & 1.00 & & 0.79 & 1.63 & & 0.67 & 0.68 & 0.86 \\
\hline$m 2 \# 12$ & 1.07 & 0.62 & & & 1.40 & 1.39 & 0.51 & & 1.20 & & m2\#12 & & & & & & & & & & \\
\hline$m 2 \# 13$ & 1.13 & 1.14 & & & 1.36 & 1.08 & 0.58 & 1.38 & 0.84 & & $m 2 \# 13$ & & & & & & 3.24 & & & & \\
\hline m2\#14 & 1.76 & 1.09 & & & 1.50 & 2.10 & 0.77 & 0.61 & 0.84 & 1.09 & m2\#14 & & 0.82 & & & & 0.58 & & 0.86 & & 0.56 \\
\hline m2\#15 & 0.25 & 0.16 & & & 0.22 & 0.47 & 0.41 & 0.19 & 0.32 & 0.27 & m2\#15 & & 0.32 & & & & 0.32 & & 0.14 & 0.14 & 0.15 \\
\hline$m 6 \# 13$ & 0.36 & 0.71 & 0.59 & & 0.20 & 0.24 & 0.55 & 0.22 & 0.31 & 0.24 & m6\#13 & & 0.44 & & & & 0.47 & & 0.32 & 0.34 & 0.27 \\
\hline m6\#31 & 1.67 & 0.89 & & & 1.12 & 1.06 & 0.83 & 1.42 & 0.88 & 0.88 & m6\#31 & & 1.41 & & & & 0.70 & & & & \\
\hline$m 6 \# 42$ & 0.63 & 0.95 & 0.31 & & 0.50 & 0.81 & 1.39 & 1.02 & 0.95 & 0.82 & m6\#42 & 0.74 & 1.81 & 0.70 & & & 2.00 & & 1.01 & 1.00 & 0.96 \\
\hline$m 6 \# 43$ & 0.47 & 0.64 & 0.79 & & 0.90 & 0.68 & 3.10 & & 1.09 & 0.88 & m6\#43 & & 1.45 & 0.53 & & & 1.52 & & & & \\
\hline Rm6\#1 & 1.01 & 0.28 & 0.83 & & 0.20 & 0.45 & 0.41 & 0.55 & 0.54 & 0.45 & $\mathrm{Rm} 6 \# 1$ & & 0.53 & 1.07 & & & 0.65 & & 0.61 & 0.46 & 0.60 \\
\hline Rm6\#2 & 0.93 & 1.01 & 1.18 & & 0.60 & 1.16 & 0.86 & 0.92 & 1.60 & 0.92 & Rm6\#2 & & 0.63 & 1.35 & & & 1.28 & & 0.83 & 0.63 & 0.62 \\
\hline s3\#22 & 1.67 & 1.94 & 1.95 & & 1.12 & 1.64 & 2.04 & 1.94 & 2.03 & 1.26 & s3\#22 & & 1.04 & 3.51 & & & 1.22 & & 1.11 & 1.26 & 1.62 \\
\hline s3\#51 & 0.08 & 0.25 & 0.27 & & 0.10 & 0.11 & 0.23 & 0.14 & 0.48 & 0.64 & s3\#51 & & 0.17 & 0.25 & & & 0.36 & 0.22 & 0.56 & 0.46 & 0.27 \\
\hline s3\#52 & 0.21 & & & & 0.14 & 0.26 & 0.18 & 0.22 & 0.24 & 0.33 & s3\#52 & & & & & & 0.98 & & 0.25 & 0.26 & 0.20 \\
\hline s3\#54 & 0.20 & & 0.65 & & & & 0.10 & 0.14 & 0.12 & 0.10 & s3\#54 & & & & & & & & 0.29 & 0.21 & \\
\hline s5\#12 & 0.55 & 0.93 & 0.47 & & 0.42 & 0.88 & 0.98 & 0.46 & 0.75 & 0.43 & s5\#12 & & 0.37 & 1.36 & & & 0.53 & & 0.92 & 0.65 & 0.32 \\
\hline s5\#32 & 0.99 & & 0.23 & & 0.83 & 0.82 & 0.12 & 0.12 & 0.11 & 0.10 & s5\#32 & & & 0.36 & & & & 0.51 & 0.59 & 0.40 & 0.30 \\
\hline s5\#33 & 0.08 & 0.08 & 0.28 & & 0.08 & 0.09 & 0.11 & 0.10 & 0.09 & 0.18 & $s 5 \# 33$ & & 0.25 & 0.20 & & & 0.21 & 0.21 & 0.29 & 0.27 & 0.25 \\
\hline s5\#34 & 0.21 & 0.15 & 0.47 & & 0.35 & 0.24 & 0.29 & 0.26 & 0.26 & 0.10 & s5\#34 & & 0.21 & 0.40 & & & 0.23 & 0.45 & 0.37 & 0.42 & 0.26 \\
\hline Rs5\#1 & 0.85 & 0.65 & 0.44 & & 0.76 & 0.33 & 0.44 & 0.35 & 0.65 & 0.64 & Rs5\#1 & & 0.47 & 0.97 & & & 0.88 & 1.10 & 0.30 & 0.30 & 0.26 \\
\hline Rs5\#2 & 0.25 & 0.33 & 0.60 & & 0.72 & 0.47 & 0.54 & 0.36 & 0.85 & 0.67 & Rs5\#2 & & 0.36 & 0.67 & & & 0.44 & 0.82 & 1.38 & 0.99 & 0.86 \\
\hline
\end{tabular}


Attempts to isolate the anhydride were unsuccessful, and therefore $s 3$ was conjugated to OVA and HRP by the active ester method. The obtained hapten-to-protein molar ratios of all available conjugates are listed in Table S1. Those values were 5 consistent with the number of free $\varepsilon$-amines available in the carriers.

\section{Animal immunization and monoclonal antibody production}

In previous studies, mAbs against CPPU had been prepared using haptens with the spacer arm at the para position of the 10 phenylurea ring and with different lengths ( $p 2$ and $p 6$ ) as immunizing haptens. ${ }^{8 \mathrm{a}}$ To complete our collection of mAbs, mice were immunized with conjugates of $m$-type and $s$-type haptens (BSA- $m 2$, BSA- $m 6, \mathrm{BSA}-s 3$, and BSA $-s 5$ ). A summary of the $\mathrm{mAb}$-generation process is reported in Table $\mathrm{S} 2$ of the ESI $\dagger$. To a 15 set of 17 mAbs previously generated using haptens $p 2$ and $p 6,21$ novel antibodies were added: 4 cell lines from mice immunized with BSA- $m 2,4$ from BSA-m6, 6 from BSA-s3, and 7 from BSA-s5. All of the produced $m A b s$ were of the $\mathrm{IgG}_{1}$ isotype (only mAb $m 6 \# 43$ was of the $\operatorname{IgG}_{2 b}$ isotype) with a $\kappa$-type light 20 chain. Additionally, $6 \mathrm{pAbs}$ had been generated from rabbits immunized with the three site-heterologous haptens containing the longer linker $(p 6, m 6$, and $s 5){ }^{8}$

\section{Structure-activity relationship}

Evaluation of antibody affinity

25 A preliminary characterization of a set of $38 \mathrm{mAbs}$ was performed in two cELISA formats using coating conjugates or enzyme tracers carrying the homologous hapten, that is, the same synthetic derivative used for immunization. Antibody affinity was estimated from the concentration of analyte at the inflection point 30 of the fitted inhibition curve, typically corresponding to a $50 \%$ reduction $\left(\mathrm{IC}_{50}\right)$ of the maximum absorbance $\left(\mathrm{A}_{\max }\right)$ if the background signal approaches to zero. As a foremost result, an $\mathrm{IC}_{50}$ value below $1.0 \mathrm{nM}$ was displayed by $70 \%$ of the mAbs in the i-cELISA format, and by $38 \%$ of the mAbs in the d-cELISA 35 format. High-affinity antibodies could be produced from all immunogens, independently of the derivatization site and linker length of the hapten. Based on this study, $4 \mathrm{mAbs}$ from each immunizing conjugate were selected. With the aim of assessing the effect of hapten heterology on the apparent affinity of the 40 generated antibodies, heterologous conjugates were also

i-cELISA

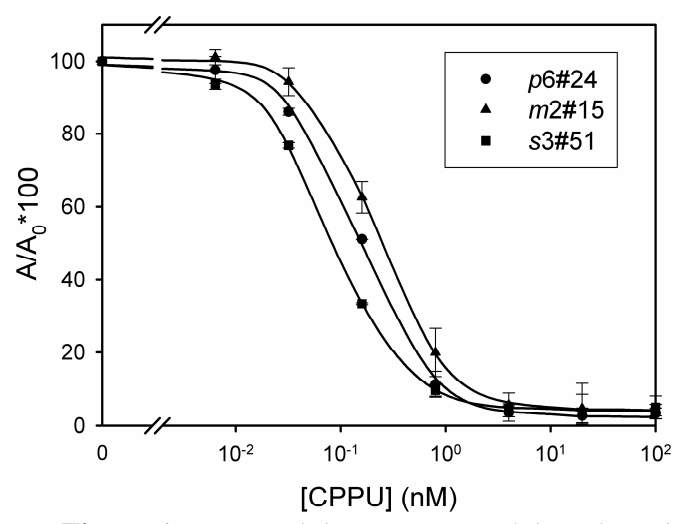

employed in both cELISA formats. For each combination of immunoreagents different concentrations were tested, so a collection of inhibition curves with different $A_{\max }$ values was obtained. Table 2 summarizes this study for the selected $24 \mathrm{mAbs}$ 45 and the 6 available rabbit pAbs. The diversity of the prepared haptens allowed us to find some heterologous combinations which could lower the $\mathrm{IC}_{50}$ values. Cell color in Table 2 indicates the heterologous combinations that provided $\mathrm{IC}_{50}$ values lower than the homologous one. Around one third of the mAbs clearly 50 improved their binding to CPPU using heterologous conjugates.

Although it was difficult to draw solid conclusions about the type of heterology that exerted a higher improvement on the $\mathrm{IC}_{50}$ values of antibodies, some general trends were observed. First, linker-length heterology was not shown as a very effective 55 strategy. Second, structural heterology resulted in rare improvements on assay sensitivity; conjugates based on haptens $4 \mathrm{Fs} 5$ and $4 \mathrm{Ms} 5$, with modifications at the phenyl ring, were better recognized and performed finer than those employing haptens with changes at the chloropyridyl ring, i.e. haptens CldPhUp6 and ${ }_{60} \mathrm{PhPyU}$ 6. Third, site-heterology was revealed as the most successful approach, as the vast majority of the combinations that afforded improved CPPU recognition were based on haptens with the spacer arm at a position different to that of the immunizing hapten. Fourth, enzyme tracers with short spacer arms were 65 mostly not recognized; this experimental observation has been frequently documented for other antigens. ${ }^{13}$ Fifth, it was found that the response of every particular antibody was not parallel in both assay formats. As it generally happens, ${ }^{14}$ the d-cELISA format showed a more restrictive recognition pattern towards 70 assay conjugates than the i-cELISA format. Finally, the behaviour of the pAbs was equivalent to that shown by the mAbs, although pAbs generally displayed a broader recognition profile of heterologous conjugates. This result may be attributed to the fact that the pAbs

75 represent the raw response of the animal immune system, and therefore they comprise immunoglobulins with heterogeneous properties.

Figure 1 shows a representative inhibition curve for one $\mathrm{mAb}$ from each functionalization site in both cELISA formats, using as 80 selection criteria the apparent affinity of the antibody and the slope of the inhibition curve. Those curves had $\mathrm{A}_{\max }$ values

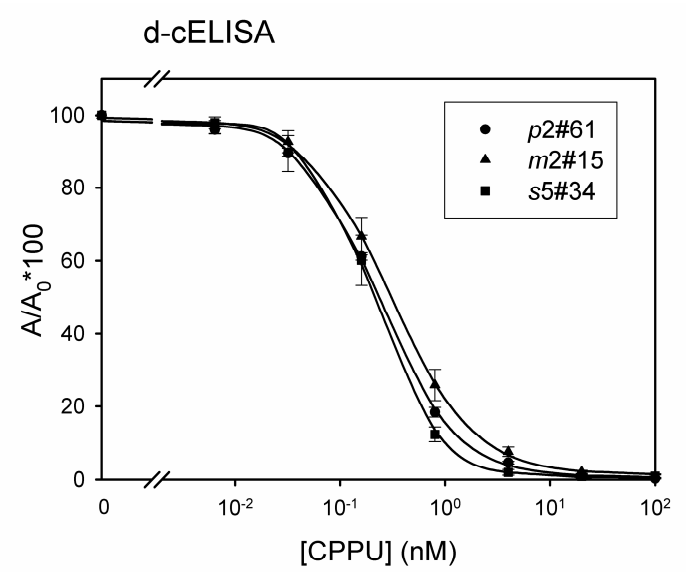

Figure 1 CPPU inhibition curves of the selected antibodies in two cELISA formats. Values are the average of three independent experiments 
around 1.0 and showed $\mathrm{IC}_{50}$ values below $0.3 \mathrm{nM}$ and slopes around -1.2. A detailed list of the parameters of the depicted curves is provided in Table $\mathrm{S} 3$ of the ESI $\dagger$.

\section{Binding studies by hierarchical clustering analysis}

5 The evaluation of antibody-antigen interactions has opened the door to promising biomedical applications in the diagnosis, prognosis, and therapeutic fields, or even in vaccine development research. ${ }^{15}$ Assessment of antibody specificity is traditionally conducted by cross-reactivity studies, where a set of molecules 10 structurally related to the target analyte are evaluated as competitors. By studying the analogue recognition (AR) pattern of antibodies, the major antigenic determinants within the target molecule can be disclosed. Nevertheless, the heterogeneity sometimes displayed by antibodies can make it difficult to 15 establish a relationship between the structure of the immunizing hapten and the binding properties of the antibodies, just by direct and non-assisted evaluation of the competitive experiments. To overcome this limitation, we have performed a wide analysis of the AR pattern for a large panel of antibodies and we have 20 applied computer-assisted clustering methodologies in order to classify the immunoglobulin repertoire. These informatics tools, commonly employed in genomic and transcriptomic analysis, have been proven as very helpful instruments to correlate and to assist the comprehension of large sets of data from proteomic ${ }_{25}$ studies $^{16}$ and they have also been applied to profiling antibody binding properties to proteins or peptides. ${ }^{17}$ Recently, Pattathil et $a l .{ }^{18}$ published the application of this agglomerative method in order to group mAbs, based on plant cell wall polysaccharide recognition patterns. In the present study, hierarchical clustering 30 analysis has been applied for the first time to the evaluation of the specificity of antibodies generated against a small organic molecule. To determine the binding properties of $38 \mathrm{mAbs}$ and 6 rabbit pAbs that were produced against CPPU, a study was carried out using a group of synthetic compounds (see the

35 Experimental section) which are chemically related to CPPU (see the list and their abbreviations in Table 3). Those analogues could be classified into three categories depending on the chemical modification under consideration: first, chemicals with changes at the phenyl ring (4FPhClPyU, 4MePhClPyU, $\mathrm{F}_{5} \mathrm{PhClPyU}$, and ${ }_{40} \mathrm{CldPyU}$ ); second, analogues with changes at the chloropyridyl ring (PhBrPyU, PhdClPyU, PhPyU, dPhU, NdPhU, and CldPhU); and third, those with modifications at the urea bridge (thio-CPPU and $\mathrm{BzClPyA}$ ). Additionally, the recognition of herbicide thidiazuron (TDZ), which presents a thiadiazole ring instead of 45 the characteristic chloropyridyl ring of CPPU, was also assessed. From the data matrix of AR values of those compounds, a specificity heat map was generated as illustrated in Figure 2A. Also a dendrogram was created (see the left of the heat map) to easily classify the antibodies according to their specificity 50 profiles by implementing a hierarchical clustering algorithm ${ }^{19}$ using the MeV software (see the Experimental section). In that classification tree, the antibodies represented in closer positions are mathematically the most similar, and therefore the distance between clusters (groups of antibodies) can be correlated to the 55 similarity of the binding profiles. As it can be observed, two well differentiated groups of antibodies had been generated by immunization with six CPPU derivatives. The first cluster, called A (light green bar), included only antibodies obtained from immunizing haptens that had been functionalized at the phenyl
Table 3 Chemical structures of the CPPU analogues used as competitors in the AR studies.

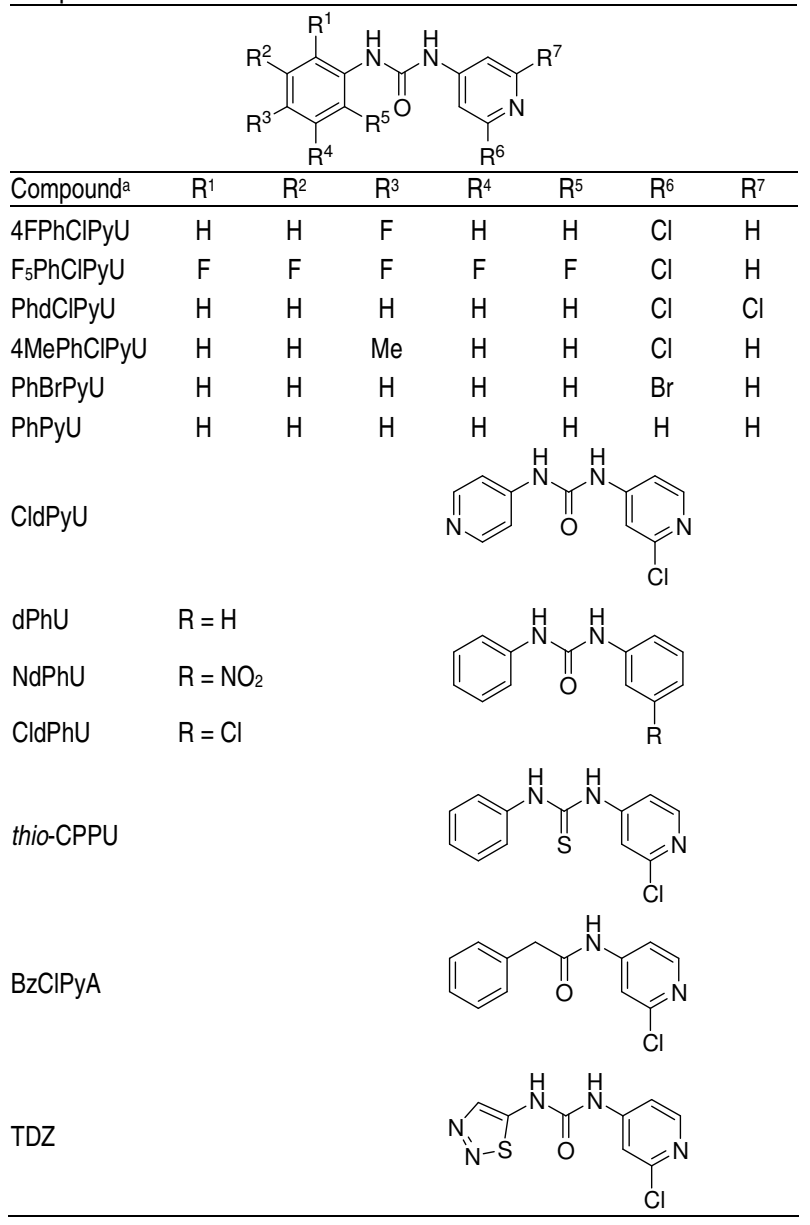

${ }_{60}$ ring $(p 2, p 6, m 2$, and $m 6)$, whereas the second cluster, called B (pink bar), was composed mainly of antibodies obtained from haptens derivatized at the chloropyridyl ring ( $s 3$ and $s 5)$. Antibodies belonging to cluster A seemed to be more permissive to changes in the structure of the phenyl ring of the competing 65 analogues (4FPhClPyU, 4MePhClPyU, F 5 PHCLPYU, and CldPyU) than antibodies of cluster B. A clear example of the differential response between both groups was observed for compound CldPyU. Most antibodies of cluster A were able to recognize this chemical to a similar extent or even better than 70 CPPU, whereas for antibodies of cluster B, the distal substitution of the phenyl ring by a pyridyl ring (as in CldPyU) caused a noticeable disturbance in the recognition. On the contrary, lower AR values towards compounds with modifications at the chloropyridyl ring (PhBrPyU, PhdClPyU, PhPyU, dPhU, NdPhU, 75 and $\mathrm{CldPhU}$ ) were generally found for antibodies in cluster A than for antibodies in cluster B. This trend was especially evident for compounds $\mathrm{NdPhU}$ and $\mathrm{CldPhU}$, which were characterized by the substitution of the 2-chloropyridyl ring by a nitrophenyl and chlorophenyl ring, respectively (see Table 3). This observation 80 highlighted the important role of the nitrogen atom of the pyridine ring in the interaction of the antibodies with CPPU. Altogether, these findings were in agreement with the Landsteiner's principle $^{20}$ as antibodies showed a higher interaction with those moieties distally located from the 


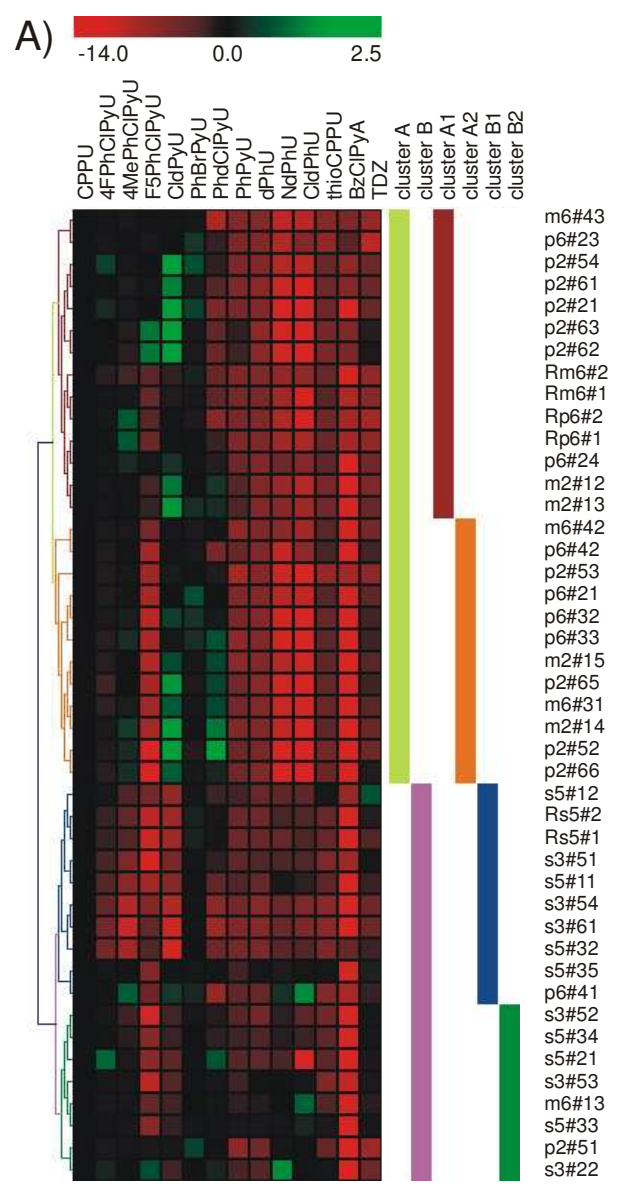

B)

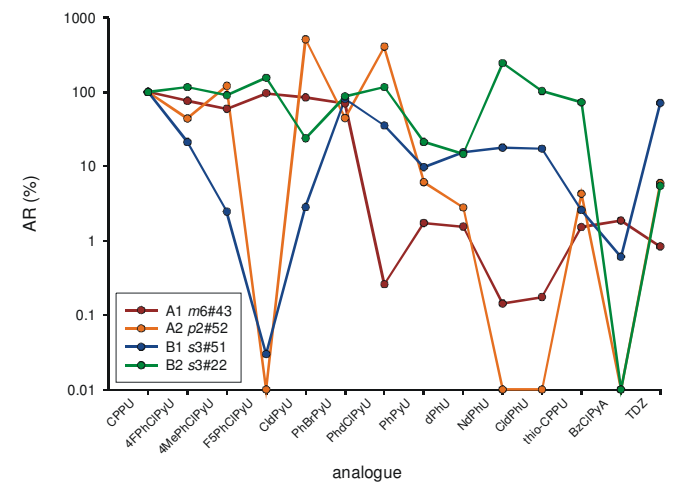

C)

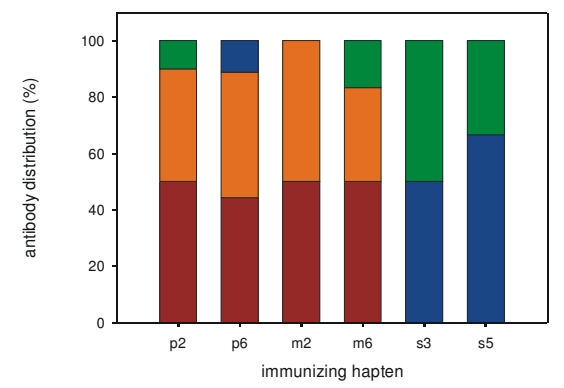

Figure 2 Analysis of the binding properties of the antibodies to a set of CPPU analogous compounds. A) Heat map visualization of the logarithm of AR data matrix and the generated dendrogram using the hierarchical Kendall's Tau similarity metric and complete linkage as the aggregation method. Black represents $100 \%$ binding. Intense green means that AR was much over 100\%, whereas intense red means that binding was much lower than $100 \%$. B) AR profiles of representative antibodies of the main clusters of the dendrogram. C) Correlation between the original immunizing hapten and antibody distribution within the clusters.

attachment site of the spacer arm. In contrast, modifications at positions closer to the derivatization site were better tolerated. The classification of the antibodies based on hierarchical clustering analysis clearly evidenced that the position of the 5 functionalized arm within the immunizing hapten, and hence the variation in the displayed orientation of the CPPU framework, had a significant influence on antibody specificity.

Both clusters A and B could be further subdivided into two branches, called $\mathrm{A} 1$ and $\mathrm{A} 2$, and $\mathrm{B} 1$ and $\mathrm{B} 2$, respectively. To 10 better visualize differences among clusters, the AR profile of a representative $\mathrm{mAb}$ from each group has been depicted in Figure 2B. The main difference among antibodies of branches A1 (dark red line) and A2 (orange line) was the recognition of compounds $\mathrm{F}_{5} \mathrm{PhClPyU}$ and PhdClPyU. Whereas antibodies of branch A1 15 showed a certain tolerance towards the presence of five fluorineatoms at the phenyl ring $\left(\mathrm{F}_{5} \mathrm{PhClPyU}\right)$, antibodies of branch A2 were clearly more susceptible to this electronic modification, following a more similar behavior to some antibodies in cluster B. In contrast, the presence of two chlorine 20 atoms at the pyridyl ring (PhdClPyU) was quite well tolerated by most antibodies of branch A2. Regarding cluster B, antibodies comprising branch B1 (blue line) presented a narrower binding profile than those included in branch B2 (dark green line), as evidenced by the lower AR values of the former antibodies, thus 25 being more sensitive to modifications in the CPPU structure.
Both Rp6-type and both Rm6-type rabbit pAbs shared their binding profiles with antibodies of cluster A (branch A1), whereas both Rs5-type rabbit pAbs were included into cluster B (branch B1), as it would be expected attending to the hapten from 30 which they were derived.

Some other significant findings with respect to relevant epitopes in the target molecule were ascertained from the analysis of the binding heat map (Figure 2A). First, PhBrPyU was perfectly recognized by all of the antibodies, independently of 35 their origin. On the contrary, a general loss of binding was observed for compound PhPyU, that is, the analogue lacking the chlorine atom (see Table 3). These results suggested that the presence of an electron-withdrawing element at the C-2 position of the pyridyl ring was highly important, being chlorine and 40 bromine atoms perfectly exchangeable, as also observed by other authors with different targets. ${ }^{21}$ The significance of the presence of a polarized area in the antigen was also supported by the high recognition displayed by some antibodies towards analogue PhdClPyU. Similar results were found by Schneider et al. ${ }^{22}$ for 45 antibodies produced against the phenylurea herbicide monuron. Accordingly, the modification of the urea bridge in phenylurea compounds has often been found to cause a disturbance in the antibody recognition. ${ }^{23}$ The strong contribution of the urea bridge to the antibody-antigen interaction was revealed by a general ${ }_{50}$ decrease in the recognition of the thiourea analogue (thio-CPPU), 


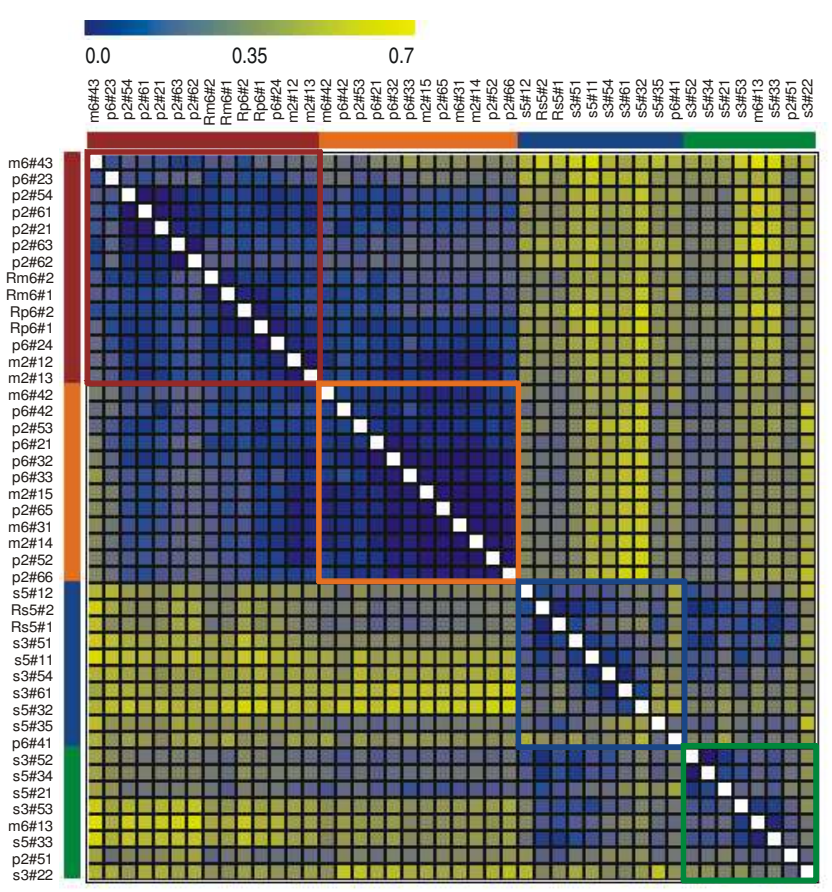

Figure 3 Heat map visualization of the antibody-distance matrix obtained by implementation of Kendall's tau similarity metric. The measures are represented in a scale ranging from 0 (highest similarity, blue) to 1 (lowest similarity, yellow), indicating perfect agreement and disagreement for every pair of antibodies, respectively.

and especially by an almost undetectable binding to the amide analogue (BzClPyA). The lower recognition of the structurally similar thio-CPPU can be probably attributed to the different hydrogen bond pattern showed by the ureido and thioureido 5 moieties due to the higher acidity of the thioureidic hydrogens and, particularly, the much weaker hydrogen-bond acceptor capability of the thiocarbonyl group. ${ }^{24}$ Concerning TDZ recognition, a highly diverse binding was observed; some mAbs, such as $p 6 \# 23$, showed low AR values, whereas other antibodies 10 such as $s 5 \# 12$ presented recognition over $100 \%$. The medium-tohigh binding pattern displayed by most of the mAbs to TDZ represents a clear indication of the bioisosterism ${ }^{25}$ that occurs between the chloropyridine and the thiadiazole moieties. Finally, chemicals with just one of the aromatic rings such as 4-amino-215 chloropyridine and $N$-phenylurea, or with no ring at all such as $N, N^{\prime}$-dimethylurea, were not recognized, thus indicating the contribution of the whole molecule to a tight interaction with the antibody binding site.

Based on the results herein presented, it could be hypothesized 20 that the interaction between the generated antibodies and CPPU could be in first instance mainly driven by electrostatic forces, being in this sense the polarization associated to the 2-chloropyridyl ring highly determinant. Then, the antibodyantigen complex may be strengthened by formation of hydrogen 25 bonds involving the ureido group and/or the nitrogen atom of the chloropyridyl ring. These results would fit with a cave-like binding pocket characteristic of hapten-antibody interactions. ${ }^{26}$ Recently, Kopečný et al. ${ }^{27}$ resolved the crystal structure of CPPU in a complex with enzyme ZmCKO1, a cytokinin 30 oxidase/dehydrogenase of Zea mays which becomes inactivated upon binding with this synthetic phytoregulator. In the most feasible conformation, the 2-chloropyridyl ring is internally oriented to interact with the enzyme cofactor, thus allowing the stabilization of the enzyme-substrate interaction probably by the 35 formation of hydrogen bonding between the hydrogen atoms in the urea bridge and a neighbouring aspartic acid residue within the active site.

As observed in Figure 2C, no disparity on antibody specificity was found regarding the derivatization positions, para or meta, at 40 the phenyl ring, as antibodies obtained from those immunogens were similarly distributed within cluster A, with few antibodies included in cluster B. On the other hand, $s$-type antibodies (coming from haptens derivatized at the pyridyl ring) were all included in cluster B and evenly distributed among both ${ }_{45}$ subgroups. With respect to the spacer arm, it was observed that the assayed linker lengths generated equivalent specificity responses. As a final approach, the whole collection of antibodies was used to create a heat map representing the antibody distance (Figure 3). The minimum and maximum Kendall's tau $(\tau)$ 50 correlation coefficients extracted from the comparison between the four clusters, and the corresponding pairs of antibodies are listed in Table S4 in the $\mathrm{ESI}^{\dagger}$. A higher similarity was found among antibodies included in cluster A, especially in branch A2 $\left(\tau_{\min }=0.60 ; \tau_{\max }=0.98\right)$, than among antibodies in cluster $\mathrm{B}\left(\tau_{\min }\right.$ ${ }_{55}=0.01 ; \tau_{\max }=0.80$ for branch B1). Therefore, it could be concluded that immunogens of the $p$-type and $m$-type generated a more homogeneous immune response in terms of specificity than immunogens of the s-type.

\section{Conclusions}

${ }_{60}$ Monoclonal antibodies with peculiar or somehow deviated behaviours from the average response are occasionally generated. ${ }^{28}$ In this study, the high number of available antibodies allowed us to establish a correlation between immunogen structure and antibody specificity. Good molecular mimicking 65 was achieved by all immunizing derivatives as reflected by the high affinity of the generated antibodies. For sensitivity improvement, modification of the functionalization site of the assay competitor was demonstrated as the most successful approach. Besides, the applied strategy using chemical analogues 70 was especially useful for gaining some insights into the most significant epitopes involved in the antibody-antigen interaction. Also, the potential of computer-assisted classification techniques as complementary tools for the comprehension of the diversity of the generated immune response towards a small chemical 75 molecule has been demonstrated. The recently discovered influence of CPPU in septin organization could make the synthesized chemicals and the developed antibodies herein described very useful reagents in basic research about this important family of proteins.

\section{${ }_{80}$ Experimental}

Analytical-grade standard forchlorfenuron [1-(2-chloro-4pyridyl)-3-phenylurea, CAS Registry No. 68157-60-8, MW 247.7 $\mathrm{g} / \mathrm{mol}$ was purchased from Sigma-Aldrich-Fluka (Madrid, Spain). Chemical reactions were monitored by thin-layer 
chromatography with $0.25 \mathrm{~mm}$ precoated silica gel plates. The synthesized chemicals were purified by flash column chromatography on silica gel 60 (particle size $=40-63 \mu \mathrm{m}$ ). Melting points were obtained in a Kofler hot-stage apparatus or a 5 Büchi melting point apparatus and are uncorrected.

Carrier proteins, adjuvants, fetal bovine serum (FBS), culture media, and other biochemical reagents were from Sigma-Aldrich (Madrid, Spain) or Roche Applied Science (Mannheim, Germany). Purification of protein-hapten conjugates and 10 antibodies was carried out in Sephadex G-25 HiTrap Desalting columns and HiTrap Protein G HP columns, respectively, acquired from GE Healthcare (Uppsala, Sweden). P3-X63Ag8.653 mouse plasmacytoma cell line was obtained from the European Collection of Cell Cultures (Wiltshire, UK). Polyclonal 15 goat anti-rabbit immunoglobulin peroxidase conjugate (GAR-HRP) was purchased from Bio-Rad (Madrid, Spain) and polyclonal rabbit anti-mouse immunoglobulin peroxidase conjugate (RAM-HRP) was from Dako (Glostrup, Denmark).

\section{Hapten synthesis}

20 Although most of the chemicals used in this work present minor or usual safety concerns, it is recommended to take special caution for the handling of acyl azides and isocyanates. The syntheses of haptens $p 2, p 6, m 6, s 5$, CldPhUp6, and PhPyUp6 were described in previous articles. ${ }^{8}$ The procedures employed

25 for the synthesis of immunogens $m 2$ and $s 3$ (Scheme 1) were as explained below. The details of the synthesis of assay derivatives $4 \mathrm{Fs} 5$ and $4 \mathrm{Ms} 5$ (Scheme S1), and the spectroscopic characterization data of the new compounds are given in the $\mathrm{ESI}^{\dagger}$. Synthesis of hapten $m 2$

${ }_{30}$ To prepare hapten $m 2 \quad(\mathbf{4})$, the commercial 2-(3-aminophenyl)acetic acid (1) was reacted with 2-chloro-4isocyianatopyridine (3). A solution of 2-chloroisonicotinoyl azide $(2,149 \mathrm{mg}, 0.82 \mathrm{mmol})^{12}$ in toluene $(1.0 \mathrm{~mL})$ was added drop wise to a stirred solution of $\mathbf{1}(117 \mathrm{mg}, 0.78 \mathrm{mmol})$ in anhydrous 35 toluene $(1.2 \mathrm{~mL})$ at reflux under inert atmosphere. The reaction mixture was stirred for $1.5 \mathrm{~h}$ at reflux and then cooled to $\mathrm{rt}$. The solid was collected by filtration and washed with toluene and ethyl ether, and dried under vacuum to give pure 2-(3-(3-(2-chloropyridin-4-yl)ureido)phenyl)acetic acid, hapten $40 \mathrm{~m} 2(\mathbf{4}, 200 \mathrm{mg}, 85 \%)$ as a white solid: $\mathrm{mp} 197-202{ }^{\circ} \mathrm{C}$ (from toluene).

Synthesis of hapten $s 3$

2-(3-Methoxy-3-oxopropylthio)-4-nitropyridin $\mathrm{N}$-oxide (7)

A solution of the commercial methyl 3-mercaptopropionate (6, $\left.{ }_{45} 904 \mu \mathrm{L}, 8.35 \mathrm{mmol}\right)$ and $\mathrm{Et}_{3} \mathrm{~N}(1.16 \mathrm{~mL}, 8.35 \mathrm{mmol})$ in dry benzene $(10 \mathrm{~mL})$ was drop wise added to a stirred suspension of 2-chloro-4-nitropyridine $N$-oxide $(5,1.18 \mathrm{~g}, 6.76 \mathrm{mmol})^{29}$ in benzene $(23 \mathrm{~mL})$ at reflux under argon. The reaction mixture was refluxed overnight and then concentrated at reduced pressure. The

50 residue obtained was dissolved in $\mathrm{CH}_{2} \mathrm{Cl}_{2}$ and washed with water and brine. The organic layer was then dried over $\mathrm{Na}_{2} \mathrm{SO}_{4}$ and concentrated under vacuum. The residue obtained was purified by silica gel chromatography, using hexane/EtOAc 1:1 as eluent, affording the methyl ester 7 (938 mg, 54\%) as a yellow solid: $\mathrm{mp}$ $55112-114^{\circ} \mathrm{C}$ (from benzene).

Methyl 3-((4-aminopyridin-2-yl)thio)propanoate $(8)$

Iron powder $(1.00 \mathrm{~g}, 17.90 \mathrm{mmol})$ and $\mathrm{NH}_{4} \mathrm{Cl}(448 \mathrm{mg}, 8.37$ mmol) were added to a refluxed solution of compound 7 (819 mg,
$3.17 \mathrm{mmol})$ in a $4: 1$ mixture of $\mathrm{EtOH} / \mathrm{H}_{2} \mathrm{O}(25 \mathrm{~mL})$. The reaction 60 was stirred vigorously at reflux for 30-40 min, then cooled down to $\mathrm{rt}$ and filtered through a short pad of celite, using $\mathrm{MeOH}$ to wash. The filtrate was concentrated under reduced pressure, diluted with $\mathrm{CHCl}_{3}$, washed with saturated aqueous solution of $\mathrm{Na}_{2} \mathrm{CO}_{3}$ and brine, and dried over $\mathrm{Na}_{2} \mathrm{SO}_{4}$. The residue was 65 purified after concentration at vacuum by chromatography, using $\mathrm{CHCl}_{3} / \mathrm{MeOH}$ 9:1 as eluent, to give the amino ester 8 (592 mg, $88 \%)$ as a yellowish oil.

Methyl 3-(4-((3-phenylureido)pyridin-2-yl)thio)propanoate (10)

Phenyl isocyanate $(\mathbf{9}, 298 \mu \mathrm{L}, 2.74 \mathrm{mmol})$ was added drop 70 wise to a solution of methyl 3-((4-aminopyridin-2-yl)thio) propanoate $(\mathbf{8}, 466 \mathrm{mg}, 2.20 \mathrm{mmol})$ in anhydrous benzene $(8 \mathrm{~mL})$ under argon. The reaction was stirred at reflux for $3 \mathrm{~h}$ and then concentrated under reduced pressure. The residue was purified by column chromatography, using $\mathrm{CHCl}_{3} / \mathrm{MeOH}$ 95:5 as eluent, to 75 give urea-methyl ester $\mathbf{1 0}(620 \mathrm{mg}, 85 \%)$ as a white solid: $\mathrm{mp}$ $131-133^{\circ} \mathrm{C}$ (from benzene).

3-(4-((3-Phenylureido)pyridin-2-yl)thio)propanoic acid (11, hapten s3)

A solution of the urea-methyl ester 10 obtained above (190 $80 \mathrm{mg}, 0.57 \mathrm{mmol})$ in a mixture of THF $(4.5 \mathrm{~mL})$ and $\mathrm{H}_{2} \mathrm{O}(2.0 \mathrm{~mL})$ was treated with $\mathrm{LiOH} \cdot \mathrm{H}_{2} \mathrm{O}(241 \mathrm{mg}, 5.75 \mathrm{mmol})$. After $3 \mathrm{~h}$ under stirring at $\mathrm{rt}$, the reaction mixture was diluted with $\mathrm{H}_{2} \mathrm{O}(20$ $\mathrm{mL}$ ) and extracted with ethyl ether. Following removal of the remaining organic solvent under vacuum, the aqueous layer was 85 cooled on ice and acidified with $\mathrm{KHSO}_{4}$ to nearly $\mathrm{pH} \mathrm{3}$. The obtained precipitated was filtered off, washed with water and dried to give the crude product that was purified by column chromatography, using $\mathrm{CH}_{2} \mathrm{Cl}_{2} / \mathrm{MeOH}$ 7:3 as eluent, to afford hapten $s 3(\mathbf{1 1}, 128 \mathrm{mg}, 70 \%)$ as a white solid: $\mathrm{mp} 178-183{ }^{\circ} \mathrm{C}$ 90 (from $\mathrm{DMSO} / \mathrm{H}_{2} \mathrm{O}$ ).

\section{CPPU analogues}

The chemical structures of all of the employed CPPU analogues are depicted in Table 3. TDZ (1-phenyl-3-(1,2,3-thiadiazol-5yl)urea), dPhU (1,3-diphenylurea), CldPhU (1-(3-chlorophenyl)95 3-phenylurea), NdPhU (1-(3-nitrophenyl)-3-phenylurea), and PhPyU (1-(4-pyridyl)-3-phenylurea) were obtained from SigmaAldrich-Fluka (Madrid, Spain). The syntheses of 4FPhClPyU (1(2-chloro-4-pyridyl)-3-(4-fluorophenyl)urea), $\mathrm{F}_{5} \mathrm{PhClPyU}$ (1-(2chloro-4-pyridyl)-3-(2,3,4,5,6-pentafluorophenyl)urea), $4 \mathrm{MePhCl}$ $100 \mathrm{PyU}$ (1-(2-chloro-4-pyridyl)-3-p-tolylurea), PhdClPyU (1-(2,6dichloro-4-pyridyl)-3-phenylurea), CldPyU (1-(2-chloro-4pyridyl)-3-(4-pyridyl)urea), and $\mathrm{PhBrPyU}$ (1-(2-bromo-4pyridyl)-3-phenylurea) were previously described. ${ }^{8}$ The preparation of compounds thio-CPPU (1-(2-chloro-4-pyridyl)-3105 phenylthio urea) and BzClPyA ( $N$-(2-chloro-4-pyridyl)-2phenylacetamide) and their spectroscopic characterization data are detailed in the $\operatorname{ESI}^{\dagger}$ (Scheme S2).

\section{Protein-hapten conjugates}

BSA was selected for the preparation of immunogens via 110 activation of the carboxylate group of haptens with the active ester method, followed by formation of amide bonds with the free amino groups of the carrier protein. OVA and HRP were used as carriers for the i-cELISA and the d-cELISA formats, respectively. These assay conjugates were prepared by the mixed anhydride 115 method. For details see the $\mathrm{ESI}^{\dagger}$. The final hapten-to-protein 
molar ratios of the conjugates were estimated by monitoring the UV-vis spectra, assuming that the molar extinction coefficients of both species were essentially the same before and after the conjugation.

\section{Antibody production}

Mice and rabbits were immunized with BSA conjugates. The production of pAbs from haptens $p 6, m 6$ and $s 5$ has been described elsewhere. ${ }^{8}$ Also, a panel of mAbs directed against CPPU was previously generated from haptens $p 2$ and $p 6 .^{8 \mathrm{a}}$ For 10 the present study, our collection of anti-CPPU mAbs was increased and diversified from mice immunized with BSA derivatives of $m 2, m 6, s 3$, and $s 5$. The selection of hybridomas was conducted by differential i-cELISA ${ }^{30}$ using microplates that were previously coated with the homologous conjugate at 1.0 ${ }_{15} \mu \mathrm{g} / \mathrm{mL}$, and using $1 \mu \mathrm{M} \mathrm{CPPU}$ as competitor. Stable antibodysecreting clones were finally cryopreserved in liquid nitrogen and cell cultures were expanded for the production of mAbs. For further details see the $\mathrm{ESI}^{\dagger}$.

\section{Competitive immunoassays}

${ }_{20}$ Solutions of all competitors were prepared in anhydrous $N, N$ dimethylformamide and stored in amber glass vials at $-20{ }^{\circ} \mathrm{C}$. Ninety six-well polystyrene ELISA plates were coated overnight with $100 \mu \mathrm{L}$ per well of $50 \mathrm{mM}$ sodium carbonate-bicarbonate buffer, $\mathrm{pH} 9.6$ containing the corresponding immunoreagent. 25 After incubations steps, plates were washed four times with 0.15 $\mathrm{M} \mathrm{NaCl}$ containing $0.05 \%$ (v/v) Tween 20. Standard curves were prepared by serial dilutions in $10 \mathrm{mM}$ sodium phosphate-buffered saline (140 mM NaCl), pH 7.4 (PBS). The competitive step was carried out in coated microplates by mixing $50 \mu \mathrm{L}$ per well of 30 competitor solution and $50 \mu \mathrm{L}$ per well of the corresponding immunoreagent solution in PBS containing $0.05 \%$ (v/v) Tween 20 (PBST). In the case of i-cELISAs, the retained immunoglobulins were detected with an additional step using 100 $\mu \mathrm{L}$ per well of secondary antibody dilution in PBST $(1 / 10000$

${ }_{35}$ GAR-HRP and 1/2000 RAM-HRP for pAb and mAb-based assays, respectively). After washing, the enzymatic activity was revealed using $100 \mu \mathrm{L}$ per well of $2.0 \mathrm{mg} / \mathrm{mL} \quad o-$ phenylenediamine and $0.012 \%(\mathrm{v} / \mathrm{v}) \mathrm{H}_{2} \mathrm{O}_{2}$ in $25 \mathrm{mM}$ sodium citrate and $62 \mathrm{mM}$ sodium phosphate buffer, $\mathrm{pH}$ 5.4. Colour 40 development was stopped by addition of $100 \mu \mathrm{L}$ per well of 2.5 $\mathrm{M} \mathrm{H}_{2} \mathrm{SO}_{4}$. Assay times were $1 \mathrm{~h}$ for each immunological reaction and $10 \mathrm{~min}$ for signal development. All incubations were carried out at rt. ELISA absorbance was read in dual wavelength mode (492 nm with $650 \mathrm{~nm}$ as reference wavelength) and the signal 45 intensity was plotted against the analyte concentration in a logarithmic scale. The resulting sigmoidal curve was mathematically fitted to a four-parameter logistic equation using the SigmaPlot software package from SPSS Inc. (Chicago, IL).

\section{Binding studies and hierarchical clustering analysis}

${ }_{50}$ The capability of the antibodies to recognize a battery of CPPUanalogous compounds was evaluated by conducting competitive experiments in the i-cELISA format using homologous coating conjugates. Standard curves of all chemicals were prepared in PBS from concentrated stock solutions. AR was expressed as the ${ }_{55}$ percentage of the ratio between the $\mathrm{IC}_{50}$ value for $\mathrm{CPPU}$ and the $\mathrm{IC}_{50}$ value for the analogue. The binding profiles of all of the antibodies towards the evaluated chemicals were used to determine the similarity between immunoglobulins with respect to their specificity. With this purpose, a matrix of data was ${ }_{60}$ generated from the base- 2 logarithmic transformation of the AR values normalized to the unit. The corresponding heat map and the dendrogram were constructed with the MultiExperiment Viewer (MeV) version 4.5.1 (http://www.tm4.org/mev), which is a part of the TM4 Microarray Software Suite. ${ }^{31}$ The hierarchical ${ }_{65}$ classification of antibodies was performed using non-parametric Kendall's Tau similarity metric and complete linkage as the aggregation method. The antibody distance heat map was generated in the $\mathrm{MeV}$ programme by representing the distance matrix, and imposing the clustering result obtained previously.

\section{${ }_{70}$ Acknowledgements}

This work was supported by Ministerio de Educación y Ciencia (AGL2009-12940-C02/01/02/ALI), and cofinanced by FEDER Funds. C.S.P. and J.V.M. were hired by the CSIC, the former under a predoctoral $I 3 P$ contract and the latter under a Ramón $y$ ${ }_{75}$ Cajal postdoctoral contract.

We thank Laura López-Sánchez and Ana Izquierdo-Gil for excellent technical assistance.

\section{Notes and references}

${ }^{a}$ Department of Biotechnology, IATA-CSIC, Agustí Escardino 7, 46980 80 Paterna, València, Spain. Fax: +34-963636301; Tel: +34-963636301; Email:aabad@iata.csic.es

${ }^{b}$ Department of Organic Chemistry, Universitat de València, Doctor Moliner 50, 46100 Burjassot, València, Spain. Fax: +34-963544328; Tel: +34-963544509; E-mail: antonio.abad@uv.es

$85 \dagger$ Electronic Supplementary Information (ESI) available: Full characterization data of haptens $m 2$ and $s 3$ and their intermediates, syntheses and spectral data of haptens $4 \mathrm{Fs} 5$ and $4 \mathrm{M} s 5$ and those of analogues thio-CPPU and BzClPyA and their intermediates, details about the preparation and characterization of protein conjugates, the generation 90 of monoclonal antibodies, tables for the standard curve parameters and antibody-distance calculations, and copies of ${ }^{1} \mathrm{H}$ NMR, ${ }^{13} \mathrm{C}$ NMR, and mass spectra of selected compounds. See DOI: 10.1039/b000000x/

${ }^{1}$ a) M. H. Goodrow and B. D. Hammock, Anal. Chim. Acta, 1998, 376, 95 83-91; b) K. Shreder, Methods, 2000, 20, 372-379; c) M. C. Estévez-Alberola, M.-P. Marco, Anal. Bioanal. Chem., 2004, 378, 563-575; d) H. Zhang, S. Wang, J. Immunol. Methods, 2009, 350, 113.

2 a) P. Crabbe, C. van Peteghem, M. Salden and F. Kohen, J. Agric. Food 100 Chem., 2000, 48, 3633-3638; b) J. V. Mercader, C. SuárezPantaleón, C. Agulló, A. Abad-Somovilla and A. Abad-Fuentes, J. Agric. Food Chem., 2008, 56, 1545-1552; c) J. Parra, J. V. Mercader, C. Agulló, A. Abad-Fuentes, A. Abad-Somovilla, Tetrahedron, 2011, 67, 624-635.

$105^{3}$ a) R. O. Harrison, M. H. Goodrow and B. D. Hammock, J. Agric. Food Chem., 1991, 39, 122-128; b) F. I. Carroll, P. Abraham, P. K. Gong, R. R. Pidaparthi, B. E. Blough, Y. Che, A. Hampton, M. Gunnell, J. O. Lay Jr., E. C. Peterson and S. M. Owens, J. Med. Chem., 2009, 52, 7301-7309; c) C. Roucairol, S. Azoulay, M. C. Nevers, J.

110 Golebiowski, C. Créminon, J. Grassi, A. Burger and D. Duval, Bioorg. Med. Chem. Lett., 2010, 20, 987-990.

${ }^{4}$ a) J. V. Mercader, C. Agulló, A. Abad-Somovilla and A. Abad-Fuentes, Org. Biomol. Chem. Doi: 10.1039/C0OB00686F; b) Z. L. Xu, Y. D. Shen, R. C. Beier, J. Y. Yang, H. T. Lei, H. Wang and Y. M. Sun, 115 Anal. Chim. Acta, 2009, 647, 125-136; c) L. Cao, D. Kong, J. Sui, T. Jiang, Z. Li, L. Ma and H. Lin, Anal. Chem., 2009, 81, 3246-3251.

${ }^{5}$ M. I. Bruce and J. A. Zwar, Proc. R. Soc. London, Ser. B, 1966, 165, 245-265. 
${ }^{6}$ T. Okamoto, K. Shudo, S. Takahashi, F. Kawachi and Y. Isogai, Chem. Pharm. Bul., 1981, 29, 3748-3750.

${ }^{7}$ a) M. Iwase, S. Okada, T. Oguchi and A. Toh-e, Genes Genet. Syst., 2004, 79, 199-206; b) Q. Hu, W. J. Nelson and E. T. Spiliotis, J.

5 Biol. Chem., 2008, 283, 29563-29571; c) B. S. DeMay, R. A. Meseroll, P. Occhipinti and A. S. Gladfelter, Cytoskeleton, 2010, 67, 383-399.

${ }^{8}$ a) C. Suárez-Pantaleón, J.V. Mercader, C. Agulló, A. Abad-Somovilla and A. Abad-Fuentes, J. Agric. Food Chem., 2008, 56, 11122-11131; b) C. Suárez-Pantaleón, J.V. Mercader, C. Agulló, A. AbadSomovilla and A. Abad-Fuentes, J. Agric. Food Chem., 2010, 58, $8502-8511$

${ }^{9}$ a) J. M. A. Schlaeppi, W. Meyer and K. A. Ramsteiner, J. Agric. Food Chem., 1992, 40, 1093-1098; b) A. E. Karu, M. H. Goodrow, D. J.

15 Schmidt, B. D. Hammock and M. W. Bigelow, J. Agric. Food Chem., 1994, 42, 301-309; c) S. Wang, R. D. Allan, J. H. Skerrit and I. R. Kennedy, J. Agric. Food Chem., 1998, 46, $3330-3338$.

10 J. J. Manclús and A. Montoya, J. Agric. Food Chem., 1996, 44, 3703-3709.

${ }^{11}$ For examples of related nucleophilic aromatic substitution reactions, see: C. Bouillon, G. Kalopissis and G. Lang, DE Patent 2165752, 1972.

${ }^{12}$ A. Abad, C. Agulló, A. C. Cuñat, C. Vilanova and M. C. Ramírez de Arellano, Crystal Growth Design, 2006, 6, 46-57.

13 a) J. V. Mercader and A. Montoya, J. Agric. Food Chem., 1999, 47, 1276-1284; b) M. Nichkova, R. Galve and M.-P. Marco, Chem. Res. Toxicol., 2002, 15, 1360-1370.

14 a) A. Abad, M. J. Moreno and A. Montoya, J. Agric. Food Chem., 1998, 46, 2417-2426; b) N. Pastor-Navarro, C. García-Bover, A. Maquieira and R. Puchades, Anal. Bioanal. Chem., 2004, 379, 1088-1099.

15 a) P. Ellmark, C. M. Högerkorp, S. Ek, L. Belov, M. Berglund, R. Rosenquist, R. I. Christopherson and C. A. Borrebaeck, Cancer Lett., 2008, 265, 98-106; b) M. K. Han, Y. H. Oh, J. Kang, Y. P. Kim, S. Seo, J. Kim, K. Park and H. S. Kim, Proteomics, 2009, 9, 5544-5552; c) J. Zhou, L. Belov, P. Y. Huang, J. S. Shin, M. J. Solomon, P. H. Chapuis, L. Bokey, C. Chan, C. Clarke, S. J. Clarke and R. I. Christopherson, J. Immunol. Methods, 2010, 355, 40-51; d)

40 J. C. Gray, P. H. Corran, E. Mangia, M. W. Gaunt, Q. Li, K. K. Tetteh, S. D. Polley, D. J. Conway, A. A. Holder, T. BacareseHamilton, E. M. Riley and A. Crisanti, Clin. Chem., 2007, 53, 1244-1253; e) A. Pitarch, C. Nombela and C. Gil, Methods Mol. Biol., 2009, 470, 369-411.

${ }_{45}{ }^{16}$ B. Meunier, E. Dumas, I. Piec, D. Béchet, M. Hébraud and J. F. Hocquette, J. Proteome. Res., 2007, 6, 358-366.

${ }^{17}$ a) C. M. Story, E. Papa, C. C. Hu, J. L. Ronan, K. Herlihy, H. L. Ploegh and J. C. Love, Proc. Natl. Acad. Sci. U. S. A., 2008, 105, 17902-17907; b) E. Shi, W. Fury, W. Li, W. Mikulka, T. Aldrich, A.

50 Rafique, G. Chen, S. Hoffenberg, T. J. Daly and C. Radziejewski, J. Immunol. Methods, 2006, 314, 9-20.

${ }^{18}$ S. Pattathil, U. Avci, D. Baldwin, A. G. Swennes, J. A. McGill, Z. Popper, T. Bootten, A. Albert, R. H. Davis, C. Chennareddy, R. Dong, B. O'Shea, R. Rossi, C. Leoff, G. Freshour, R. Narra, M.

55 O'Neil, W. S. York and M. G. Hahn, Plant Physiol, 2010, 153, 514-525.

${ }^{19}$ M. B. Eisen, P. T. Spellman, P. O. Brown and D. Botstein, Proc. Natl. Acad. Sci. U. S. A., 1998, 95, 14863-14868.

${ }^{20}$ K. Landsteiner, in The Specificity of Serological Reactions, Harvard University Press, Cambridge, 1945.

${ }^{21}$ a) N. Sanvicens, B. Varela and M.-P. Marco, J. Agric. Food Chem., 2003, 51, 3932-3939; b) W. L. Shelver, L. M. Kamp, J. L. Church and F. M. Rubio, J. Agric. Food Chem., 2007, 55, 3758-3763.

${ }^{22}$ P. Schneider, M. H. Goodrow, S. J. Gee and B. D. Hammock, J. Agric. Food Chem., 1994, 42, 413-422.

${ }^{23}$ a) P. Degelmann, J. Wenger, R. Niessner and D. Knopp, Environ. Sci. Technol., 2004, 38, 6795-6802; b) P. M. Krämer, M. H. Goodrow and E. Kremmer, J. Agric. Food Chem., 2004, 52, 2462-2471.

${ }^{24}$ M. Kotke and P. Schreiner, in Hydrogen Bonding in Organic Synthesis, 70 ed. P. M. Pihko, Willey-VCH, Weinheim, 2009, p. 145.
${ }^{25}$ L. Moreira-Lima and E. J. Barreiro, Curr. Med. Chem., 2005, 12, 23-49.

${ }^{26}$ M. Lee, P. Lloyd, X. Zhang, J. M. Schallhorn, K. Sugimoto, A. G. Leach, G. Sapiro and K. N. Houk, J. Org. Chem., 2006, 71, 5082-5092.

${ }^{27}$ D. Kopečný, P. Briozzo, H. Popelková, Š. Marek, R. Končitíková, L. Spíchal, J. Nisler, C. Madzak, I. Frébort, M. Laloue and N. HoubaHérin, Biochimie, 2010, 92, 1052-1062.

${ }^{28}$ J. J. Manclús, M. J. Moreno, E. Plana and A. Montoya, J. Agric. Food Chem., 2008, 56, 8793-8800.

${ }^{29}$ G. C. Finger and L. D. Starr, J. Am. Chem. Soc., 1959, 81, 2674-2675.

${ }^{30}$ J. V. Mercader, J. Primo and A. Montoya, J. Agric. Food Chem., 1995, 43, 2789-2793.

${ }^{31}$ a) A. I. Saeed, N. K. Bhagabati, J. C. Braisted, W. Liang, V. Sharov, E. A. Howe, J. Li, M. Thiagarajan, J. A. White and J. Quackenbush, Methods Enzymol., 2006, 411, 134-93; b) A. I. Saeed, V. Sharov, J. White, J. Li, W. Liang, N. Bhagabati, J. Braisted, M. Klapa, T. Currier, M. Thiagarajan, A. Sturn, M. Snuffin, A. Rezantsev, D. Popov, A. Ryltsov, E. Kostukovich, I. Borisovsky, Z. Liu, A. 90 Vinsavich, V. Trush and J. Quackenbush, BioTechniques, 2003, 34, 374-378.

Limited amounts of the newly described chemicals and immunoreagents are available upon request for evaluation. 


\section{$\underline{\text { Electronic Supplementary Information }}$}

\section{Forchlorfenuron-Mimicking Haptens: from Immunogen Design to}

\section{Antibody Characterization by Hierarchical Clustering Analysis}

Celia Suárez-Pantaleón, ${ }^{\dagger}$ Josep V. Mercader, ${ }^{\dagger}$ Consuelo Agullo,${ }^{\S}$ Antonio Abad-Somovilla ${ }^{\S}$ and Antonio Abad-Fuentes ${ }^{\dagger}$

\footnotetext{
${ }^{\dagger}$ Department of Biotechnology, IATA-CSIC, Agustí Escardino 7, 46980 Paterna, València, Spain.

${ }^{\S}$ Department of Organic Chemistry, Universitat de València, Doctor Moliner 50, 46100 Burjassot, València, Spain.
}

\section{TABLE OF CONTENTS}

1. General spectroscopic techniques

2. Spectroscopic characterization data of haptens $m 2$ and $s 3$ and intermediates of their synthesis (Scheme 1 in the article)

3. Preparation of haptens $4 \mathrm{Fs} 5$ and $4 \mathrm{M} s 5$ (Scheme S1)

4. Preparation of CPPU analogues thio-CPPU and BzClPyA (Scheme S2)

5. Preparation of protein conjugates (Table S1)

6. Monoclonal antibody production (Table S2)

7. Standard curve parameters (Table S3)

8. Antibody-distance data (Table S4)

9. Copies of ${ }^{1} \mathrm{H}$ NMR, ${ }^{13} \mathrm{C}$ NMR, and mass spectra of haptens $m 2, s 2,4 \mathrm{Fs} 5$, and $4 \mathrm{M} s 5$ 


\section{General spectroscopic techniques}

NMR spectra were recorded in $\mathrm{CDCl}_{3}$ or DMSO- $d_{6}$ at room temperature on a Bruker AC-300 spectrometer (300.13 MHz for ${ }^{1} \mathrm{H}$ and $75.47 \mathrm{MHz}$ for ${ }^{13} \mathrm{C}$ ). The spectra were referenced to residual solvent protons in the ${ }^{1} \mathrm{H}$ NMR spectra (7.26 and $\left.2.50 \mathrm{ppm}\right)$ and to solvent carbons in the ${ }^{13} \mathrm{C}$ NMR spectra (77.00 and $39.43 \mathrm{ppm})$. Carbon substitution degrees were established by distortionless enhancement by polarization transfer pulse sequences. A combination of correlation spectroscopy and heteronuclear single quantum coherence experiments was used for the assignment of ${ }^{1} \mathrm{H}$ and ${ }^{13} \mathrm{C}$ chemical shifts. IR spectra were measured as thin films between $\mathrm{NaCl}$ plates and $\mathrm{KBr}$ pellets for liquid and solid compounds, respectively, in a Nicolet Avatar 320 spectrometer. Electron-impact (EI) and fast atom bombardment (FAB) mass spectra (MS and HRMS) were carried out in a Micromass VG Autospec spectrometer. Extinction coefficients were calculated in $100 \mathrm{mM}$ sodium phosphate buffer, $\mathrm{pH} 7.4(\mathrm{~PB})$.

2. Spectroscopic characterization data of haptens $m 2$ and $s 3$ and intermediates of their synthesis (Scheme 1 in the article)

\section{2-(3-(3-(2-Chloropyridin-4-yl)ureido)phenyl)acetic acid (4, hapten $m 2)$}

${ }^{1} \mathrm{H}$ NMR (DMSO-d6), $\delta: 12.33$ (1H, br s, OH), 9.32 and 8.99 (1H each, each s, two NH), $8.17(1 \mathrm{H}$, d, $J=5.9 \mathrm{~Hz}, \mathrm{H}-6 \mathrm{Py}), 7.66(1 \mathrm{H}, \mathrm{d}, J=1.8 \mathrm{~Hz}, \mathrm{H}-3 \mathrm{Py}), 7.39(1 \mathrm{H}, \mathrm{br}$ s, H-2 Ph), 7.33 (1H, m partially overlapped with dd at 7.31, H-4 Ph), $7.31(1 \mathrm{H}, \mathrm{dd}, J=5.7,1.9 \mathrm{~Hz}, \mathrm{H}-5 \mathrm{Py}), 7.24(1 \mathrm{H}, \mathrm{t}, J=$ $7.7 \mathrm{~Hz}, \mathrm{H}-5 \mathrm{Ph}), 6.91(1 \mathrm{H}$, br d, $J=7.6 \mathrm{~Hz}, \mathrm{H}-6 \mathrm{Ph}), 3.53(2 \mathrm{H}, \mathrm{s}, \mathrm{H}-2) ;{ }^{13} \mathrm{C}$ NMR $\left(\mathrm{CDCl}_{3} / \mathrm{DMSO}-d 6\right), \delta: 172.59$ (C-1), 151.82 (NCON), 150.96 (C-4 Py), 149.93 (C-6 Py), 149.12 (C-2 Py), 138.74 (C-3 Ph), 135.68 (C-1 Ph), 128.72 (C-5 Ph), 123.79 (C-6 Ph), 119.56 (C-2 Ph), 117.05 (C-4 Ph), 111.88 (C-3 Py), 111.24 (C-5 Py), 40.80 (C-2); IR (KBr): 3400-2130, 1715, 14601620, 1375, 1183, 778, 723, 641, $443 \mathrm{~cm}^{-1}$; MS (EI) m/z: $305\left(\mathrm{M}^{+}, 7.3\right), 287$ (2), 261 (9), 177 (33), 
154 (86), 151 (100); HRMS: calcd for $\mathrm{C}_{14} \mathrm{H}_{12} \mathrm{ClN}_{3} \mathrm{O}_{3}$ 305.05672, found 305.05541; UV (PB), $\varepsilon$ (280 $\mathrm{nm})=11.35 \mathrm{mM}^{-1} \mathrm{~cm}^{-1}, \varepsilon(260 \mathrm{~nm})=28.19 \mathrm{mM}^{-1} \mathrm{~cm}^{-1}$.

\section{3-((4-(3-Phenylureido)pyridin-2-yl)thio)propanoic acid (11, hapten s3)}

2-(3-Methoxy-3-oxopropylthio)-4-nitropyridine $N$-oxide (7):

${ }^{1} \mathrm{H}$ NMR $\left(\mathrm{CDCl}_{3}\right), \delta: 8.31(1 \mathrm{H}, \mathrm{d}, J=7.2 \mathrm{~Hz}, \mathrm{H}-6 \mathrm{Py}), 8.03(1 \mathrm{H}, \mathrm{d}, J=3.0 \mathrm{~Hz}, \mathrm{H}-3 \mathrm{Py}), 7.89(1 \mathrm{H}$, dd, $J=7.2,3.0 \mathrm{~Hz}, \mathrm{H}-5 \mathrm{Py}), 3.67\left(3 \mathrm{H}, \mathrm{s}, \mathrm{OCH}_{3}\right), 3.28(2 \mathrm{H}, \mathrm{t}, J=7.2 \mathrm{~Hz}, \mathrm{H}-1), 2.82(2 \mathrm{H}, \mathrm{t}, J=7.2$ $\mathrm{Hz}, \mathrm{H}-2) ;{ }^{13} \mathrm{C} \mathrm{NMR}\left(\mathrm{CDCl}_{3}\right), \delta$ : 170.98 (C-3), 153.88 (C-2 Py), 142.52 (C-4 Py), 139.08 (C-6 Py), 115.62 and $114.92(\mathrm{C}-3$ and $\mathrm{C}-5 \mathrm{Py}), 52.30\left(\mathrm{OCH}_{3}\right), 32.46(\mathrm{C}-2), 25.69(\mathrm{C}-1)$; IR (KBr): 3100, $3073,3015,2950,1739,1574,1522,1458,1434,1197,1147,873,744,651 \mathrm{~cm}^{-1}$; MS (EI), m/z: 258 (M+, 22), 242 (25), 241 (70), 227 (16), 225 (7), 211 (15), 209 (100), 199 (16), 183 (44), 182 (35), 172 (46), 163 (23), 153 (24); HRMS: calcd for $\mathrm{C}_{9} \mathrm{H}_{10} \mathrm{~N}_{2} \mathrm{O}_{5} \mathrm{~S} 258.03104$, found 258.03076.

Methyl 3-((4-aminopyridin-2-yl)thio)propanoate (8):

${ }^{1} \mathrm{H}$ NMR $\left(\mathrm{CDCl}_{3}\right), \delta: 8.04(1 \mathrm{H}, \mathrm{d}, J=5.7 \mathrm{~Hz}, \mathrm{H}-6 \mathrm{Py}), 6.42(1 \mathrm{H}, \mathrm{d}, J=2.3 \mathrm{~Hz}, \mathrm{H}-3 \mathrm{Py}), 6.27(1 \mathrm{H}$, dd, $J=5.7,2.3 \mathrm{~Hz}, \mathrm{H}-5 \mathrm{Py}), 4.09\left(2 \mathrm{H}\right.$, br s, $\left.\mathrm{NH}_{2}\right), 3.69\left(3 \mathrm{H}, \mathrm{s}, \mathrm{OCH}_{3}\right), 3.37(2 \mathrm{H}, \mathrm{t}, J=7.2 \mathrm{~Hz}, \mathrm{H}-3)$, $2.76(2 \mathrm{H}, \mathrm{t}, J=7.2 \mathrm{~Hz}, \mathrm{H}-2) ;{ }^{13} \mathrm{C} \mathrm{NMR}\left(\mathrm{CDCl}_{3}\right), \delta: 172.63$ (C-1), 158.30 (C-2 Py), 152.62 (C-4 Py), 149.65 (C-6 Py), 107.15 (C-3 Py), 106.84 (C-5 Py), $51.72\left(\mathrm{OCH}_{3}\right), 34.72$ (C-2), 24.94 (C-3); IR (film): 3465, 3375, 3210, 3005, 2950, 1734, 1636, 1592, 1550, 1479, 1437, 1360, 1258, 1132, 981, $823 \mathrm{~cm}^{-1}$; MS (EI) m/z: $212\left(\mathrm{M}^{+}, 20\right), 181$ (7), 179 (7), 155 (4), 154 (9), 153 (100), 152 (4), 139 (12), 127 (20), 126 (26); HRMS: calcd for $\mathrm{C}_{9} \mathrm{H}_{12} \mathrm{~N}_{2} \mathrm{O}_{2} \mathrm{~S} 212.06195$, found 212.06131.

Methyl 3-(4-((3-phenylureido)pyridin-2-y)lthio)propanoate (10):

${ }^{1} \mathrm{H}$ NMR $\left(\mathrm{CDCl}_{3}\right), \delta: 8.10(1 \mathrm{H}, \mathrm{d}, J=6.0 \mathrm{~Hz}, \mathrm{H}-6 \mathrm{Py}), 7.90$ and 7.74 (1H each, each br s, two NH), 7.30-7.20 (4H, m, H-2/H-6 and H-3/H-5 Ph), 7.19 (1H, d, J = 1.9 Hz, H-3 Py), 7.05 (1H, m, H-4 Ph), $6.95(1 \mathrm{H}, \mathrm{dd}, J=6.0,1.9 \mathrm{~Hz}, \mathrm{H}-5 \mathrm{Py}), 3.67\left(3 \mathrm{H}, \mathrm{s}, \mathrm{OCH}_{3}\right), 3.35(2 \mathrm{H}, \mathrm{t}, J=7.2 \mathrm{~Hz}, \mathrm{H}-3)$, $2.75(2 \mathrm{H}, \mathrm{t}, J=7.2 \mathrm{~Hz}, \mathrm{H}-2) ;{ }^{13} \mathrm{C} \mathrm{NMR}\left(\mathrm{CDCl}_{3}\right), \delta: 173.24(\mathrm{C}-1), 158.80(\mathrm{C}-2 \mathrm{Py}), 152.83$ (NCON), 149.72 (C-6 Py), 146.24 (C-4 Py), 137.36 (C-1 Ph), 129.22 (C-3/C-5 Ph), 124.47 (C-4 Ph), 120.88 (C-2/C-6 Ph), 110.57 (C-3 Py), 110.04 (C-5 Py), $52.01\left(\mathrm{OCH}_{3}\right), 34.50$ (C-2), 25.23 (C-3); IR (KBr): 3392, 3354, 2950, 1722, 1698, 1579, 1540, 1439, 1275, 1200, 1083, 1002, $753 \mathrm{~cm}^{-1}$; MS (EI) m/z: 
$331\left(\mathrm{M}^{+}, 5\right), 330$ (1), 298 (1), 273 (2), 272 (13), 238 (14), 212 (8), 179 (82), 153 (36), 119 (45), 93 (100); HRMS: calcd for $\mathrm{C}_{16} \mathrm{H}_{17} \mathrm{~N}_{3} \mathrm{O}_{3} \mathrm{~S} 331.09906$, found 331.09777.

3-((4-(3-Phenylureido)pyridin-2-yl)thio)propanoic acid (11, hapten s3):

${ }^{1} \mathrm{H}$ NMR (DMSO-d6), $\delta: 12.34(1 \mathrm{H}$, br s, OH), 9.52 and $9.27(1 \mathrm{H}$ each, each br s, two $\mathrm{NH}), 8.21$ $(1 \mathrm{H}, \mathrm{d}, J=5.7 \mathrm{~Hz}, \mathrm{H}-6 \mathrm{Py}), 7.50-7.45(3 \mathrm{H}, \mathrm{m}, \mathrm{H}-2 / \mathrm{H}-6 \mathrm{Ph}$ and H-3 Py), $7.28(2 \mathrm{H}, \mathrm{t}, J=7.9 \mathrm{~Hz}$, H-3/H-5 Ph), $7.11(1 \mathrm{H}, \mathrm{dd}, J=5.7,1.9 \mathrm{~Hz}, \mathrm{H}-5 \mathrm{Py}), 6.99$ (1H, tt, $J=7.9,1.2 \mathrm{~Hz}, \mathrm{H}-4 \mathrm{Ph}), 3.27(2 \mathrm{H}$, $\mathrm{t}, J=7.0 \mathrm{~Hz}, \mathrm{H}-5), 2.60(1 \mathrm{H}, J=7.0 \mathrm{~Hz}, \mathrm{H}-2) ;{ }^{13} \mathrm{C}$ NMR (DMSO-d6), $\delta: 173.50(\mathrm{C}-1), 158.28(\mathrm{C}-2$ Py), 152.14 (NCON), 149.59 (C-6 Py), 146.93 (C-4 Py), 139.13 (C-1 Ph), 128.73 (C-3/C-5 Ph), 122.26 (C-4 Ph), 118.49 (C-2/C-6 Ph), 109.25 (C-3 Py), 108.75 (C-5 Py), 34.62 (C-2), 24.83 (C-3); IR (KBr): 3550-2400, 3306, 2922, 1731, 1599, 1557, 1189, 1083, $751 \mathrm{~cm}^{-1}$; MS (EI) m/z: $317\left(\mathrm{M}^{+}\right.$, 0.5), 290 (0.6), 273 (0.8), 245 (1.5), 224 (1.2), 198 (5), 180 (10), 153 (17), 126 (67), 119 (71), 93 (100); HRMS (FAB): calcd for $\mathrm{C}_{15} \mathrm{H}_{16} \mathrm{~N}_{3} \mathrm{O}_{3} \mathrm{~S}$ [M+1] 318.09124, found 318.09063; UV (PB), $\varepsilon$ (280 $\mathrm{nm})=11.31 \mathrm{mM}^{-1} \mathrm{~cm}^{-1}, \varepsilon(260 \mathrm{~nm})=29.88 \mathrm{mM}^{-1} \mathrm{~cm}^{-1}$.

\section{Preparation of haptens $4 \mathrm{Fs} 5$ and $4 \mathrm{Ms} 5$}

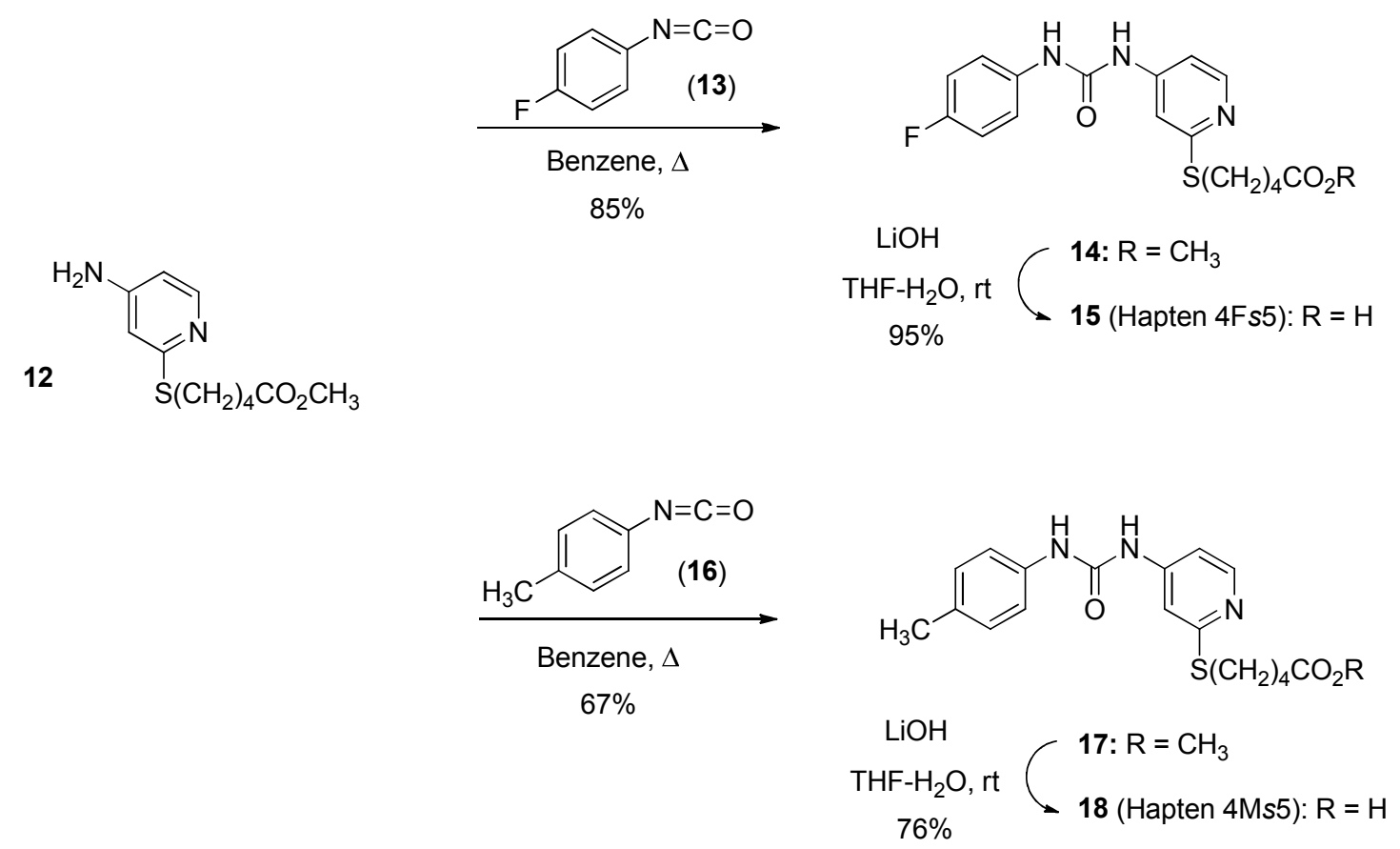

Scheme S1. Preparation of haptens 4Fs5 and 4Ms5 
5-(4-(3-((4-Fluorophenyl)ureido)pyridin-2-yl)thio)pentanoic acid (15, hapten 4Fs5)

Methyl 5-((4-(3-(4-fluorophenyl)ureido)pyridin-2-yl)thio)pentanoate (14). Methyl 5-((4aminopyridin-2-yl)thio)pentanoate (12) was synthesized as described previously for the preparation of hapten $s 5 .{ }^{1}$ Then, 4-fluorophenyl isocyanate $(13,29 \mu \mathrm{L}, 0.26 \mathrm{mmol})$ was added drop wise to a solution of the amino ester $12(57 \mathrm{mg}, 0.24 \mathrm{mmol})$ in benzene $(1.0 \mathrm{~mL})$. After $1 \mathrm{~h} 45 \mathrm{~min}$ at reflux under argon, the reaction mixture was diluted with hexane and the solid was filtrated affording the urea-methyl ester 14 (76 mg, 85\%) as a white solid: mp $154-158{ }^{\circ} \mathrm{C}$ (from acetone). ${ }^{1} \mathrm{H}$ NMR (acetone-d6), $\delta: 8.43$ and 8.31 (1H each, two s, two NH), $8.19(1 \mathrm{H}, \mathrm{d}, J=5.7 \mathrm{~Hz}, \mathrm{H}-6 \mathrm{Py}), 7.56-7.52$ (3H, m, H-3 Py and H-2/H-6 Ph), 7.12 (1H, dd, J = 5.7, 1.8 Hz, H-5 Py), 7.10-7.04 (2H, m, H-3/H-5 $\mathrm{Ph}), 3.61\left(3 \mathrm{H}, \mathrm{s}, \mathrm{CO}_{2} \mathrm{CH}_{3}\right), 3.17(2 \mathrm{H}, \mathrm{t}, J=6.6 \mathrm{~Hz}, \mathrm{H}-5), 2.37(2 \mathrm{H}, \mathrm{t}, J=7.2 \mathrm{~Hz}, \mathrm{H}-2), 1.73(4 \mathrm{H}, \mathrm{m}$,

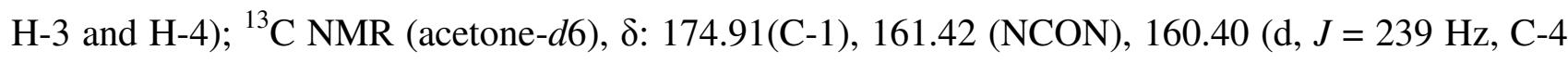
Ph), 153.89 (C-2 Py), 151.48 (C-6 Py), 148.76 (C-4 Py), 135.60 (d, J = 2.1 Hz, C-1 Ph), 122.69 (d, J $=7.5 \mathrm{~Hz}, \mathrm{C}-2 / \mathrm{C}-6 \mathrm{Ph}), 117.10(\mathrm{~d}, J=22 \mathrm{~Hz}, \mathrm{C}-3 / \mathrm{C}-5 \mathrm{Ph}), 111.25$ and $111.11(\mathrm{H}-3$ and H-5 Py), $52.50\left(\mathrm{CO}_{2} \mathrm{CH}_{3}\right), 34.85$ (C-5), 30.91 (C-2), 30.74 (C-4), 25.83 (C-3); IR (KBr): 3360, 3131, 3071, 3044, 2956, 2933, 2874, 1694, 1585, 1541, 1508, 1121, 837, $793 \mathrm{~cm}^{-1}$; MS (EI) m/z: 277 (2.5), 290 (3), 277 (7.5), 267 (3), 266 (19), 263 (3), 240 (5), 236 (2.5), 235 (18), 233 (59), 219 (5), 209 (6), 179 (82), 166 (86), 152 (64), 120 (20), 19 (22), 111 (100); HRMS (EI): calcd for $\mathrm{C}_{18} \mathrm{H}_{20} \mathrm{FN}_{3} \mathrm{O}_{3} \mathrm{~S}$ [M $\left.{ }^{+}\right]$ 377.12094, found 377.12086.

5-(4-(3-((4-Fluorophenyl)ureido)pyridin-2-yl)thio)pentanoic acid (15, hapten 4Fs5). Hapten 4Fs5 was obtained by hydrolysis of the methyl ester moiety of compound $\mathbf{1 4}(62 \mathrm{mg}, 0.16 \mathrm{mmol})$ with $\mathrm{LiOH} \cdot \mathrm{H}_{2} \mathrm{O}(69 \mathrm{mg}, 1.65 \mathrm{mmol})$ during $6 \mathrm{~h}$, as described for hapten $s 3$ (see Experimental section in the article). After ethyl ether extraction and acidification of the aqueous layer with $\mathrm{KHSO}_{4}$, followed by extraction with AcOEt and work up afforded nearly pure hapten $4 \mathrm{Fs} 5(\mathbf{1 5}, 57 \mathrm{mg}, 95 \%)$ as a white solid: mp 197-199 ${ }^{\circ} \mathrm{C}$ (from DMSO/H $\mathrm{H}_{2} \mathrm{O}$ ). ${ }^{1} \mathrm{H}$ NMR (DMSO-d6), $\delta: 12.03$ (1H, broad s, OH), 9.21 y 9.24 (1H each, two s, two NH), $8.20(1 \mathrm{H}, \mathrm{d}, J=5.7 \mathrm{~Hz}, \mathrm{H}-6 \mathrm{Py}), 7.49-7.43$ (3H, m, H-3 Py

\footnotetext{
${ }^{1}$ C. Suárez-Pantaleón, J.V. Mercader, C. Agulló, A. Abad-Somovilla and A. Abad-Fuentes, J. Agric. Food Chem. 2010, 58, 8502-8511.
} 
and H-2 and H-6 Ph), 7.07 (1H, dd, $J=5.7,1.9 \mathrm{~Hz}, \mathrm{H}-5 \mathrm{Py}), 7.13$ (2H, m, H-3 and H-5 Ph), 3.10 $(2 \mathrm{H}, \mathrm{t}, J=6.6 \mathrm{~Hz}, \mathrm{H}-5), 2.24(2 \mathrm{H}, \mathrm{t}, J=6.6 \mathrm{~Hz}, \mathrm{H}-2), 1.63(4 \mathrm{H}, \mathrm{m}, \mathrm{H}-3$ and $\mathrm{H}-4) ;{ }^{13} \mathrm{C}$ NMR

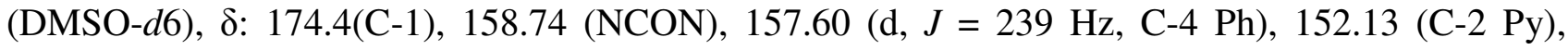
149.57 (C-6 Py), 146.74 (C-4 Py), 135.34 (d, $J=2.3$ Hz, C-1 Ph), 120.40 (d, $J=7.7$ Hz, C-2/C-6 Ph), 115.28 (d, $J=22 \mathrm{~Hz}, \mathrm{C}-3$ and C-5 Ph), 109.16 and 108.75 (H-3 and H-5 Py), 33.24 (C-5), 28.76 and 28.54 (C-2 and C-4), 23.73 (C-3); IR (KBr): 3340-3276, 3153, 3073, 2956, 2934, 2918, 2718, 1565, 1509, 1192, 830, $740 \mathrm{~cm}^{-1}$; MS (EI) m/z: 207 (1), 138 (5), 137 (70), 112 (4), 111 (53), 110 (6), 108 (4), 73 (100); HRMS (FAB): calcd for $\mathrm{C}_{17} \mathrm{H}_{19} \mathrm{FN}_{3} \mathrm{O}_{3} \mathrm{~S}\left[\mathrm{M}^{+}+1\right]$ 364.11312, found 364.11276; $\mathrm{UV}(\mathrm{PB}), \varepsilon(280 \mathrm{~nm})=8.00 \mathrm{mM}^{-1} \mathrm{~cm}^{-1}, \varepsilon(260 \mathrm{~nm})=25.44 \mathrm{mM}^{-1} \mathrm{~cm}^{-1}$.

\section{5-(4-((3-p-Tolylureido)pyridin-2-yl)thio)pentanoic acid (18, hapten 4Ms5)}

Methyl 5-((4-(3-p-tolylureido)pyridin-2-yl)thio)pentanoate (17). p-Tolyl isocyanate (16, $32 \mu \mathrm{L}$, $0.25 \mathrm{mmol})$ was added drop wise to a solution of methyl 5-((4-aminopyridin-2-yl)thio)pentanoate $(\mathbf{1 2}, 55 \mathrm{mg}, 0.23 \mathrm{mmol})$ in dry benzene $(1.1 \mathrm{~mL})$ under inert atmosphere. The reaction was stirred for $1 \mathrm{~h} 45 \mathrm{~min}$ at reflux and then it was diluted with hexane and filtrated to afford the corresponding urea-methyl ester 17 (57 mg, 67\%) as a yellowish solid: mp 136-140 ${ }^{\circ} \mathrm{C}$ (from acetone). ${ }^{1} \mathrm{H}$ NMR (acetone- $d 6), \delta: 8.37$ and $8.17(1 \mathrm{H}$ each, two s, two NH), $8.19(1 \mathrm{H}, \mathrm{d}, J=5.8 \mathrm{~Hz}, \mathrm{H}-6 \mathrm{Py}), 7.54(1 \mathrm{H}$, d, $J=1.6 \mathrm{~Hz}, \mathrm{H}-3 \mathrm{Py}), 7.40$ (2H, m, H-2 and H-6 Ph), 7.13-7.06 (3H, $m, \mathrm{H}-5$ Py and H-3 and H-5 $\mathrm{Ph}), 3.61\left(3 \mathrm{H}, \mathrm{s}, \mathrm{CO}_{2} \mathrm{CH}_{3}\right), 3.17(2 \mathrm{H}, \mathrm{t}, J=7.0 \mathrm{~Hz}, \mathrm{H}-5), 2.35(2 \mathrm{H}, \mathrm{t}, J=7.0 \mathrm{~Hz}, \mathrm{H}-2), 2.27(3 \mathrm{H}, \mathrm{s}$, $\mathrm{CH}_{3}-\mathrm{Ph}$ ), 1.73 (4H, m, H-3 and H-4); ${ }^{13} \mathrm{C}$ NMR (acetone-d6), $\delta$ 174.91(C-1), 161.36 (NCON), 153.81 (C-2 Ph), 151.44 (C-6 Py), 148.88 (C-4 Py), 138.53 (C-4 Ph), 133.91 (C-1 Ph), 131.07 (C-3 and C-5 Ph), 120.94 (C-2 and C-6 Ph), 111.17 and $111.06(\mathrm{H}-3$ and $\mathrm{H}-5 \mathrm{Py}), 52.50\left(\mathrm{CO}_{2} \mathrm{CH}_{3}\right), 34.85$ (C-5), 30.92 (C-2), 30.74 (C-4), 25.83 (C-3), $21.72\left(\mathrm{CH}_{3}-\mathrm{Ph}\right)$; IR (KBr): 3364, 1698, 1595, 1535, 1480, 1362, 1168, 821, $630 \mathrm{~cm}^{-1}$; MS (EI) m/z: 373 (3), 286 (3), 273 (10), 266 (18), 259 (4), 240 (7), 235 (18), 233 (4), 219 (5), 179 (75), 166 (77), 165 (19), 153 (28), 106 (100); HRMS (EI): calcd for $\mathrm{C}_{19} \mathrm{H}_{23} \mathrm{~N}_{3} \mathrm{O}_{3} \mathrm{~S}\left[\mathrm{M}^{+}\right]$373.14601, found 373.14703.

5-((4-(3-p-Tolylureido)pyridin-2-yl)thio)pentanoic acid (18, hapten 4Ms5). The hydrolysis of the ester moiety of $17(57 \mathrm{mg}, 0.15 \mathrm{mmol})$ was carried out essentially as described for haptens $s 3$ and 
4Fs5, using $\mathrm{LiOH} \cdot \mathrm{H}_{2} \mathrm{O}(65 \mathrm{mg}, 1.54 \mathrm{mmol})$. After ethyl ether extraction and acidification of the aqueous layer, the precipitated solid was filtered and dried under vacuum to give pure hapten $4 \mathrm{M} s 5$ (18, $42 \mathrm{mg}, 76 \%$ ) as a white solid: $\mathrm{mp} 198-201{ }^{\circ} \mathrm{C}$ (from $\left.\mathrm{MeOH}\right) .{ }^{1} \mathrm{H}$ NMR (DMSO-d6), $\delta: 12.02$ $(1 \mathrm{H}$, broad s, OH), 9.06 and $8.79(1 \mathrm{H}$ each, two s, two NH), $8.19(1 \mathrm{H}, \mathrm{d}, J=5.6 \mathrm{~Hz}, \mathrm{H}-6 \mathrm{Py}), 7.43$ $(1 \mathrm{H}, \mathrm{d}, J=1.7 \mathrm{~Hz}, \mathrm{H}-3 \mathrm{Py}), 7.33$ (2H, m, H-2 and H-6 Ph), $7.10(2 \mathrm{H}, m, \mathrm{H}-3$ and H-5 Ph), 7.06 (1H, dd, $J=5.7,1.7 \mathrm{~Hz}, \mathrm{H}-5 \mathrm{Py}), 3.10(2 \mathrm{H}, \mathrm{t}, J=7.0 \mathrm{~Hz}, \mathrm{H}-5), 2.24$ (2H, t, $J=7.3 \mathrm{~Hz}, \mathrm{H}-2), 1.63$ (4H, m, H-3 and H-4); ${ }^{13} \mathrm{C}$ NMR (DMSO- $\left.d 6\right), \delta: 174.26(\mathrm{C}-1), 158.71$ (NCON), 151.98 (C-2 Ph), 149.55 (C6 Py), 146.75 (C-4 Py), 136.35 (C-4 Ph), 131.28 (C-1 Ph), 129.15 (C-3 and C-5 Ph), 118.60 (C-2 and C-6 Ph), 109.10 and 108.66 (H-3 and H-5 Py), 33.13 (C-5), 28.74 and 28.53 (C-2 and C-4), 23.67 (C-3), $20.29\left(\mathrm{CH}_{3}-\mathrm{Ph}\right)$; IR (KBr): 3115, 3049, 3022, 2945, 1720, 1606, 1560, 1508, 1406, 1315, 1204, 841, $818 \mathrm{~cm}^{-1}$; MS (EI) m/z: 133 (10), 132 (5), 108 (1), 107 (14), 106 (18), 105 (1.5), 91 (2), 73 (100); HRMS (FAB): calcd for $\mathrm{C}_{18} \mathrm{H}_{22} \mathrm{~N}_{3} \mathrm{O}_{3} \mathrm{~S}\left[\mathrm{M}^{+}+1\right]$ 360.13819, found 360.13877; UV (PB), $\varepsilon(280 \mathrm{~nm})=14.51 \mathrm{mM}^{-1} \mathrm{~cm}^{-1}, \varepsilon(260 \mathrm{~nm})=30.75 \mathrm{mM}^{-1} \mathrm{~cm}^{-1}$.

\section{Preparation of CPPU analogues thio-CPPU and BzCIPyA}

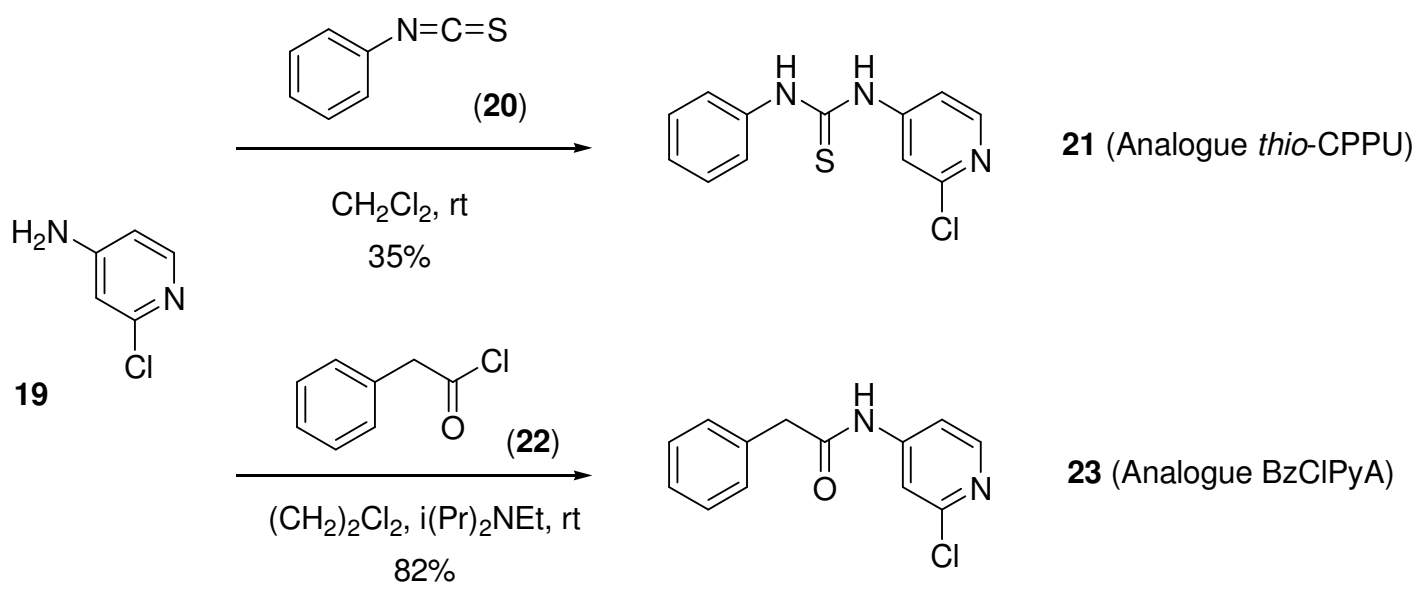

Scheme S2. Preparation of CPPU analogues thio-CPPU and BzClPyA 


\section{1-(2-Chloro-4-pyridyl)-3-phenylthiourea (21, thio-CPPU)}

Phenyl isothiocyanate $(\mathbf{2 0}, 354 \mu \mathrm{L}, 1.86 \mathrm{mmol})$ was added drop wise via syringe to a solution of 4-amino-2-chloropyridine $(\mathbf{1 9}, 217 \mathrm{mg}, 1.69 \mathrm{mmol})^{2}$ in dry $\mathrm{CH}_{2} \mathrm{Cl}_{2}(2.0 \mathrm{~mL})$ and then stirred at $\mathrm{rt}$ for $120 \mathrm{~h}$. The reaction mixture was then extracted with $\mathrm{CH}_{2} \mathrm{Cl}_{2}$, washed with water and brine, and dried over $\mathrm{Mg}_{2} \mathrm{SO}_{4}$ to give the crude product that was purified by column chromatography, using $\mathrm{CH}_{3} \mathrm{Cl} / \mathrm{MeOH}$ 9:1 as eluent. The eluted fraction containing the product was extracted again with AcOEt and washed with $1 \mathrm{M} \mathrm{HCl}$. The organic layer was then concentrated and dried affording thioCPPU $(\mathbf{2 1}, 154 \mathrm{mg}, 35 \%)$ as a yellow solid; mp $135-138{ }^{\circ} \mathrm{C}$ (from MeOH). ${ }^{1} \mathrm{H}$ NMR (DMSO-d6), $\delta$ : $10.40(1 \mathrm{H}, \mathrm{s}, \mathrm{NH}), 10.37$ (1H, s, NH), $8.24(1 \mathrm{H}, \mathrm{d}, J=5.6 \mathrm{~Hz}, \mathrm{H}-6 \mathrm{Py}), 7.87(1 \mathrm{H}, \mathrm{d}, J=1.8 \mathrm{~Hz}, \mathrm{H}-3$ Py), 7.54 (1H, dd, $J=5.6,1.8$ Hz, H-5 Py), 7.49 (2H, dt, $J=7.5,1.2$ Hz, H-2/H-6 Ph), 7.39 (2H, t, $J$ $=7.5, \mathrm{~Hz}, \mathrm{H}-3 / \mathrm{H}-5 \mathrm{Ph}), 7.19(1 \mathrm{H}, \mathrm{tt}, J=7,5,1,2 \mathrm{~Hz}, \mathrm{H}-4 \mathrm{Ph}) ;{ }^{13} \mathrm{C}$ NMR (DMSO-d6), $\delta: 179.08$ (NCON), 150.25 (C-4 Py), 149.72 (C-6 Py), 149.41 (C-2 Py), 138.62 (C-1 Ph), 128.61 (C-2/C-6 Ph), 125.19 (C-4 Ph), 123.79 (C-3/C-5 Ph), 114.62 and 114.15 (C-3 and C-5 Py); IR (KBr): 3152, 3115, 2968, 1589, 1569, 1528, 1488, 1190, $749 \mathrm{~cm}^{-1}$; MS (EI) m/z: 263 (8), 262 (2), 230 (15), 229 (100), 195 829, 194 (16), 178 (2), 173 (20), 170 (50); HRMS (EI): calcd for $\mathrm{C}_{12} \mathrm{H}_{10} \mathrm{ClN}_{3} \mathrm{~S}$ 263.02839, found 263.02904 .

\section{$N$-(2-Chloro-4-pyridyl)-2-phenylacetamide (23, BzCIPyA)}

2-phenylacetyl chloride $(\mathbf{2 2}, 202 \mu \mathrm{L}, 1.52 \mathrm{mmol})$ was added to a solution containing 4-amino-2chloropyridine $(\mathbf{1 9}, 98 \mathrm{mg}, 0.76 \mathrm{mmol})$ and $N, N^{\prime}$-diisopropil ethylamine (i(Pr) $)_{2} \mathrm{NEt}, 290 \mu \mathrm{L}, 1.68$ $\mathrm{mmol})$ in anhydrous 1,2-dichloroethane $(2.0 \mathrm{~mL})$. The mixture was stirred at $\mathrm{rt}$ for $1.5 \mathrm{~h}$ under inert atmosphere, then the solvent was eliminated and the crude product was diluted with water and extracted three times with EtOAc. The combined organic layers were washed with brine, dried over $\mathrm{Na}_{2} \mathrm{SO}_{4}$, and concentrated under vacuum to obtained an oil that was purified by column chromatography, using $\mathrm{CH}_{3} \mathrm{Cl}$ as eluent, to afford pure BzClPyA (23, $\left.155 \mathrm{mg}, 82 \%\right)$ as a slightly colored oil. ${ }^{1} \mathrm{H}$ NMR $\left(\mathrm{CDCl}_{3}\right), \delta: 8.70(1 \mathrm{H}, \mathrm{s}, \mathrm{NH}), 8.12(1 \mathrm{H}, \mathrm{d}, J=5.6 \mathrm{~Hz}, \mathrm{H}-6 \mathrm{Py}), 7.59(1 \mathrm{H}, \mathrm{d} J=$

\footnotetext{
${ }^{2}$ S. Kasmi-Mir, A. Djafri, L. Paquin, J. Hamelin and M. Rahmouni, Molecules, 2006, 11, 597-602.
} 
1.6 Hz, H-3 Py), 7.34-7.21 (6H, m, H-5 Py and H-2/H-3/H-4/H-5/H-6 Ph), $3.67\left(\mathrm{CH}_{2} \mathrm{O}\right) ;{ }^{13} \mathrm{C}$ NMR $\left(\mathrm{CDCl}_{3}\right), \delta: 170.46(\mathrm{CON}), 152.12$ (C-2-Py), 149.79 (C-6 Py), 147.34 (C-4 Py), 133.41 (C-1 Ph), 129.17 (C-2/C-6 Ph), 129.04 (C-3/C-5 Ph), 127.69 (C-4 Ph), 113.56 and 112.58 (C-3 and C-5 Py), $44.38\left(\mathrm{CH}_{2} \mathrm{O}\right)$; IR (KBr): 3263, 3161, 3062, 3029, 1685, 1581, 1509, 1371, 1266, 1159, 1126,1079, 837, 731, 718, $694 \mathrm{~cm}^{-1}$; MS (EI) m/z: 246 (31), 131 (2), 129 (8), 119 (3), 118 (24), 92 (29), 91 (100); HRMS (EI): calcd for $\mathrm{C}_{13} \mathrm{H}_{11} \mathrm{ClN}_{2} \mathrm{O}$ 246.05599, found 246.05649. 


\section{Preparation of protein conjugates}

Immunizing conjugate. The active ester method was used to couple haptens $m 2$ and $s 3$ to bovine serum albumin (BSA). Typically, a $100 \mathrm{mM}$ hapten solution was prepared in $N, N$ dimethylformamide (DMF) and mixed with 1 molar equivalent of $N$-hydroxysuccinimide and 1 molar equivalent of $N, N^{\prime}$-dicyclohexylcarbodiimide also in DMF. Additional DMF was added to bring the final concentration of all reagents to $50 \mathrm{mM}$. The hapten was activated overnight at $\mathrm{rt}$ in amber vials. The day after, the reaction was centrifuged and the supernatant was collected. Next, $400 \mu \mathrm{L}$ of activated $m 2$ or $s 3$ hapten solution was added drop wise to $2.0 \mathrm{~mL}$ of a $15 \mathrm{mg} / \mathrm{mL} \mathrm{BSA}$ solution in $50 \mathrm{mM}$ sodium carbonate-bicarbonate buffer, $\mathrm{pH} 9.6(\mathrm{CB})$. The coupling reaction was incubated during $4 \mathrm{~h}$ at $\mathrm{rt}$ with moderate stirring. The initial hapten-to-protein molar ratio (MR) in the mixture was approximately 44:1. Finally, the conjugate was separated from uncoupled hapten by gel filtration on Sephadex G-25, using $100 \mathrm{mM}$ sodium phosphate buffer, $\mathrm{pH} 4.4$ (PB) as eluent. The degree of hapten-to-protein conjugation was measured spectrophotometrically. If conjugation occurred, the UV-vis spectrum of the conjugate was slightly different from that of the free protein. Therefore, the final average hapten-to-protein MR was calculated from the absorbance value at 280 $\mathrm{nm}$ by assuming that the molar absorption of the hapten and the protein were the same for the free and the conjugated forms. The purified conjugate was diluted to $1.0 \mathrm{mg} / \mathrm{mL}$ with $\mathrm{PB}$ and stored at $-20{ }^{\circ} \mathrm{C}$. The calculated final hapten-to-protein MR are listed in Table S1.

Coating conjugates. Haptens $m 2, s 3,4 \mathrm{~F} s 5$, and $4 \mathrm{M} s 5$ were linked to ovalbumin (OVA) by the mixed anhydride method. Typically, $200 \mu \mathrm{L}$ of a solution with the hapten, tributylamine, and isobutyl chloroformate in DMF were prepared. The concentration of the reagents in the solution was $90 \mathrm{mM}$. After $1 \mathrm{~h}$ at $\mathrm{rt}$ with gentle stirring, $100 \mu \mathrm{L}$ of the solution containing the activated hapten was added drop wise to $2.0 \mathrm{~mL}$ of a $15 \mathrm{mg} / \mathrm{mL}$ solution of OVA in CB. In this case, the initial hapten-to-protein MR was approximately 13:1. The coupling reaction was incubated during $2.5 \mathrm{~h}$ in the same conditions as described before and then the conjugates were purified following the same 
procedure. MRs were determined by UV spectrophotometry. A solution of each conjugate was prepared at a concentration of $1.0 \mathrm{mg} / \mathrm{mL}$ in $\mathrm{PB}$ containing $0.01 \%(\mathrm{w} / \mathrm{v})$ thimerosal, and it was stored at $-20{ }^{\circ} \mathrm{C}$ for daily usage. The final MRs can be found in Table S1. Hapten $s 3$ was also coupled to OVA by the active ester method using an initial hapten-to-protein MR of 15:1.

Enzyme tracers. A $1 / 10$ dilution of the activation mixture in DMF, prepared for the previous conjugates, was employed containing $0.5 \mu \mathrm{mol}$ of the activated hapten. This dilution was added to $1.0 \mathrm{~mL}$ of a solution of horseradish peroxidase (HRP) in $\mathrm{CB}$ at a concentration of $2.2 \mathrm{mg} / \mathrm{mL}$. The initial hapten-to-protein MR in the mixture was 10:1. The conjugation was incubated during $4 \mathrm{~h}$ and then the enzyme tracer was separated from the uncoupled hapten as described before. The final MR was calculated using, in this case, the absorbance values obtained at $400 \mathrm{~nm}$ and $280 \mathrm{~nm}$. A working solution of the enzyme tracer was prepared in PBS containing $1 \%(\mathrm{w} / \mathrm{v})$ BSA and $0.01 \%(\mathrm{w} / \mathrm{v})$ thimerosal at a concentration of $0.5 \mathrm{mg} / \mathrm{mL}$ and was stored for its daily usage at $4{ }^{\circ} \mathrm{C}$. The remaining fraction was stored in elution buffer at $-20^{\circ} \mathrm{C}$. For the final MRs see Table S1. Hapten $s 3$ was also coupled to HRP by the active ester method using an initial hapten-to-protein MR of 10:1.

Table S1. Hapten-to-protein MRs of conjugates

\begin{tabular}{llcc}
\hline & \multicolumn{3}{c}{ Carrier protein } \\
\cline { 2 - 4 } Hapten & BSA & OVA & HRP \\
\hline$p 2$ & 24 & 2.8 & 2.1 \\
p6 & 30 & 2.4 & 3.4 \\
CldPhUp6 & $-a$ & 4.5 & 7.5 \\
PhPyUp6 & - & 2.5 & 1.5 \\
m2 & 34 & 1.6 & 1.3 \\
$m 6$ & 34 & 3.0 & 3.2 \\
$s 3$ & 26 & $4.0^{\mathrm{b}}$ & $1.3^{\mathrm{b}}$ \\
s5 & 18 & 6.4 & 3.3 \\
4 Fs5 & - & 5.5 & 3.5 \\
4Ms5 & - & 5.9 & 3.8 \\
\hline a Not prepared. ${ }^{b}$ These assay conjugates were prepared by the active ester \\
method.
\end{tabular}




\section{Monoclonal antibody production}

Immunization and cell fusion. Female BALB/c mice (8-10 weeks old) were immunized by intraperitoneal injections with $\mathrm{BSA}-m 2, \mathrm{BSA}-m 6, \mathrm{BSA}-s 3$, and BSA-s5 conjugates (typically 4 animals per immunogen). Initially, animals received a first dose of immunogen consisting of $100 \mu \mathrm{g}$ of conjugate in PB as a 1:1 emulsion with complete Freund's adjuvant (200 $\mu \mathrm{L}$ per mouse). Mice received two additional boosts at intervals of three weeks with the same amount of immunogen emulsified, in this case, with incomplete Freund's adjuvant. Finally, four days before cell fusions, every mouse received a last immunization containing $100 \mu \mathrm{g}$ of conjugate diluted in sterile PBS. Cell fusions were carried out following standard chemical fusion procedures ${ }^{3}$ using polyethylene glycol as fusing agent at a cellular ratio lymphocyte:myeloma of 4:1. The fused cells were cultured in 96 -well culture plates at a density between $1.5 \times 10^{5}$ and $2.5 \times 10^{5}$ cells per well in DMEM supplemented with $15 \%(\mathrm{v} / \mathrm{v})$ fetal bovine serum.

Hybridoma selection. Approximately 10 to 12 days after the fusions, the supernatants of the cultured plates were evaluated in order to identify antibody-secreting hybridomas with the ability to recognize both the coating conjugate and the free analyte. Typically, ELISA plates were coated with the homologous conjugate at a concentration of $1 \mu \mathrm{g} / \mathrm{mL}$. The supernatants were evaluated simultaneously in adjacent ELISA wells: one as blank and the other with $1 \mu \mathrm{M}$ forchlorfenuron (CPPU). Those clone-containing wells affording signal intensities in the absence of analyte close to saturation and more than 50\% inhibition under competitive conditions were selected and further cloned by limiting dilution. This process was repeated as many times as necessary in order to guarantee the stability and the monoclonal character of the cell lines. Few positive signals were observed in the screening assays of cell fusions from $s 3$ immunized mice. Therefore, two additional mice ( $s \# 5$ and $s 3 \# 6)$ were immunized with the same conjugate but the cell-fusion screening assays were performed with the OVA-s5 conjugate. Using this strategy it was possible to stabilize 5 additional hybridomas (Table S2).

\footnotetext{
${ }^{3}$ J.V. Mercader and A. Montoya, J. Agric. Food Chem., 1999, 47, 1276-1284.
} 
Monoclonal antibody purification. Immunoglobulins were purified from late stationary phase culture supernatants by ammonium sulfate precipitation followed by affinity chromatography following the manufacturer's instructions. Stock solutions of every antibody were prepared in PBS containing $1 \%(\mathrm{w} / \mathrm{v}) \mathrm{BSA}$ and $0.01 \%(\mathrm{w} / \mathrm{v})$ thimerosal and they were stored at $4{ }^{\circ} \mathrm{C}$ for daily usage. The remaining volume was 2 -fold precipitated with a saturated ammonium sulfate solution for its long-term conservation and it was stored at $4{ }^{\circ} \mathrm{C}$.

Table S2. Summary of cell fusions performed with mice immunized with conjugates BSA-m2, BSA-m6, BSA-s3, and BSA-s5

\begin{tabular}{|c|c|c|c|c|c|}
\hline \multirow[b]{2}{*}{$\begin{array}{c}\text { Immunized } \\
\text { mouse }\end{array}$} & \multirow[b]{2}{*}{$\begin{array}{l}\text { Growth } \\
\text { yielda }^{\mathrm{a}}\end{array}$} & \multicolumn{3}{|c|}{ Wells } & \multirow[b]{2}{*}{$\begin{array}{l}\text { Stabilized } \\
\text { hybridoma }\end{array}$} \\
\hline & & Cultured & Positive ${ }^{b}$ & Competitive & \\
\hline$m 2 \# 1$ & 74 & 384 & 11 & 5 & 4 \\
\hline m2\#2 & 74 & 480 & 345 & 304 & 0 \\
\hline$m 2 \# 3$ & $---d$ & & & & \\
\hline m2\#4 & --- & & & & \\
\hline m6\#1 & 42 & 384 & 13 & 10 & 1 \\
\hline m6\#2 & --- & & & & \\
\hline$m 6 \# 3$ & 67 & 384 & 9 & 1 & 1 \\
\hline m6\#4 & 73 & 288 & 210 & 195 & 2 \\
\hline$s 3 \# 1^{\mathrm{e}}$ & 79 & 288 & 0 & 0 & 0 \\
\hline$s 3 \# 2^{\mathrm{e}}$ & 49 & 288 & 225 & 171 & 1 \\
\hline s3\#3e & 54 & 240 & 0 & 0 & 0 \\
\hline s3\#4e & 21 & 288 & 3 & 2 & 0 \\
\hline$s 3 \# 5^{\dagger}$ & 76 & 576 & 20 & 9 & 4 \\
\hline$s 3 \# 6^{\dagger}$ & 62 & 672 & 10 & 2 & 1 \\
\hline s5\#1 & 77 & 384 & 89 & 77 & 2 \\
\hline s5\#2 & 85 & 384 & 56 & 43 & 1 \\
\hline s5\#3 & 77 & 672 & 491 & 472 & 4 \\
\hline s5\#4 & 17 & 192 & 0 & 0 & 0 \\
\hline \multicolumn{6}{|c|}{$\begin{array}{l}\text { a Percentage of cultured wells with cellular growth by visual inspection at day } 11 \\
\text { after fusion. }{ }^{b} \text { Wells with cellular growth affording } A_{492} \geq 1 \text { in the absence of } \\
\text { analyte. }{ }^{c} \text { Wells with an inhibition of the signal intensity } \geq 50 \% \text { in the presence of } \\
1 \mu \mathrm{M} \text { CPPU. d These mice died during the immunization process. e The } \\
\text { screening assay was performed with the conjugate OVA-s3 prepared by the } \\
\text { mixed anhydride method. }{ }^{~} \text { The screening was performed with the heterologous } \\
\text { conjugate OVA-s5. }\end{array}$} \\
\hline
\end{tabular}




\section{Standard curve parameters}

Table S3. Curve parameters of the selected cELISAs

\begin{tabular}{|c|c|c|c|c|c|c|}
\hline \multicolumn{7}{|c|}{ i-cELISA } \\
\hline$m A b$ & $\begin{array}{c}\text { OVA } \\
\text { conjugate }\end{array}$ & $\begin{array}{c}\text { [OVA conj.] } \\
(\mu \mathrm{g} / \mathrm{mL})\end{array}$ & $\begin{array}{c}\text { [mAb] } \\
\text { (ng/mL) }\end{array}$ & $A_{\max }$ & slope & $\mathrm{IC}_{50}(\mathrm{nM})$ \\
\hline p6\#24 & $4 \mathrm{Ms5}$ & 1.0 & 30 & $1.25 \pm 0.02$ & $-1.24 \pm 0.13$ & $0.16 \pm 0.01$ \\
\hline m2\#15 & m2 & 0.1 & 30 & $1.06 \pm 0.09$ & $-1.31 \pm 0.13$ & $0.22 \pm 0.04$ \\
\hline s3\#51 & p2 & 1.0 & 30 & $1.26 \pm 0.07$ & $-1.23 \pm 0.07$ & $0.08 \pm 0.01$ \\
\hline \multicolumn{7}{|c|}{ d-cELISA } \\
\hline$m A b$ & $\begin{array}{l}\text { Enzyme } \\
\text { tracer }\end{array}$ & $\begin{array}{l}\text { Tracer] } \\
(\mathrm{ng} / \mathrm{mL})\end{array}$ & $\begin{array}{c}\text { [mAb] } \\
(\mu \mathrm{g} / \mathrm{mL})\end{array}$ & $A_{\max }$ & slope & $\mathrm{IC}_{50}(\mathrm{nM})$ \\
\hline p2\#61 & $m 6$ & 10 & 1.0 & $1.23 \pm 0.03$ & $-1.13 \pm 0.09$ & $0.23 \pm 0.01$ \\
\hline m2\#15 & $m 6$ & 3 & 1.0 & $0.94 \pm 0.07$ & $-1.08 \pm 0.10$ & $0.32 \pm 0.04$ \\
\hline s5\#34 & $p 6$ & 10 & 1.0 & $0.76 \pm 0.07$ & $-1.36 \pm 0.06$ & $0.21 \pm 0.04$ \\
\hline
\end{tabular}

\section{Antibody-distance data}

Table S4. Minimum and maximum Kendall's tau correlation coefficient $(\tau)$ between antibodies by comparison of pairs of clusters ${ }^{a}$

\begin{tabular}{|c|c|c|c|c|}
\hline \multirow{2}{*}{$\begin{array}{l}\text { Confronted } \\
\text { clusters }\end{array}$} & \multicolumn{2}{|r|}{ Lowest similarity } & \multicolumn{2}{|r|}{ Highest similarity } \\
\hline & $\tau^{\mathrm{b}}$ & Representative pairs & $\tau$ & Representative pairs \\
\hline$A 1$ vs $A 1$ & 0.41 & m6\#43 vs m2\#13 & 0.96 & p2\#63 vs p2\#62 \\
\hline $\mathrm{A} 1$ vs $\mathrm{A} 2$ & 0.16 & m6\#43 vs p6\#33 & 0.82 & m2\#12 vs p2\#65/m2\#14 \\
\hline A1 vs B1 & -0.21 & m6\#43 vs s5\#11 & 0.38 & Rm6\#2 vs Rs5\#1 \\
\hline A1 vs $B 2$ & -0.25 & $m 6 \# 43$ vs $m 6 \# 13$ & 0.51 & Rm6\#1 vs s5\#21 \\
\hline $\mathrm{A} 2$ vs $\mathrm{A} 2$ & 0.60 & p6\#42 vs p6\#33 & 0.98 & $m 2 \# 15$ vs $p 2 \# 65 ; m 6 \# 31$ vs $p 2 \# 65 / m 2 \# 14$ \\
\hline $\mathrm{A} 2$ vs $\mathrm{B} 1$ & -0.18 & $p 2 \# 66$ vs $s 5 \# 32$ & 0.49 & p6\#21 vs Rs5\#1/s5\#35; p6\#33 vs Rs5\#1 \\
\hline A2 vs B2 & -0.08 & p6\#42 vs s3\#22 & 0.60 & p6\#33 vs s5\#21 \\
\hline$B 1$ vs $B 1$ & 0.01 & p6\#41 vs s5\#32 & 0.80 & Rs5\#1 vs Rs5\#2 \\
\hline $\mathrm{B} 1$ vs $\mathrm{B} 2$ & -0.05 & s5\#35 vs s3\#22 & 0.76 & Rs5\#2 vs s3\#52 \\
\hline B2 vs B2 & 0.21 & $s 3 \# 22$ vs $s 3 \# 52 / s 5 \# 34 / s 3 \# 53$ & 0.91 & s3\#52 vs s5\#34 \\
\hline
\end{tabular}


9. Copies of ${ }^{1} \mathrm{H}$ NMR, ${ }^{13} \mathrm{C}$ NMR, and mass spectra of haptens $m 2, s 2,4 \mathrm{Fs} 5$, and $4 \mathrm{Ms} 5$ 

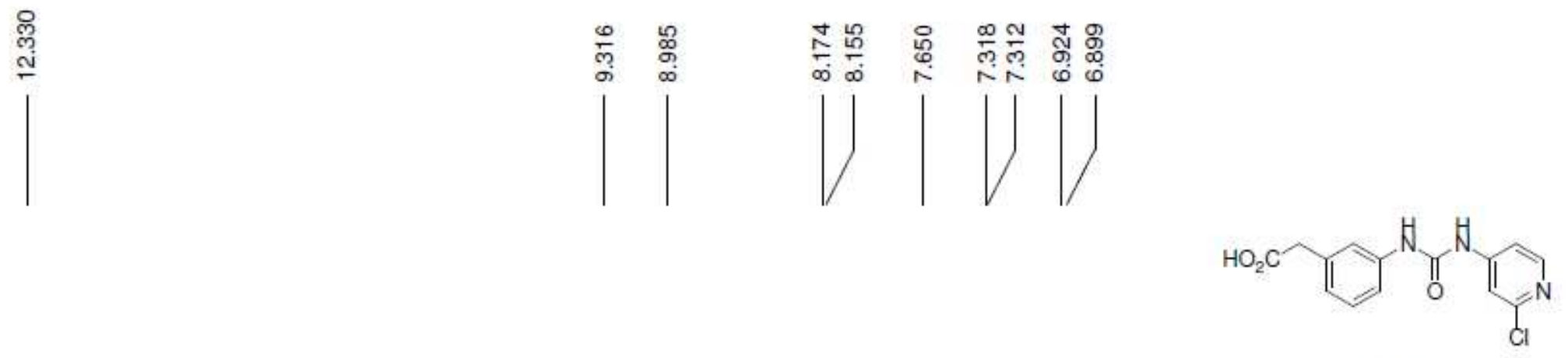

Hapten $\mathbf{m} 2$

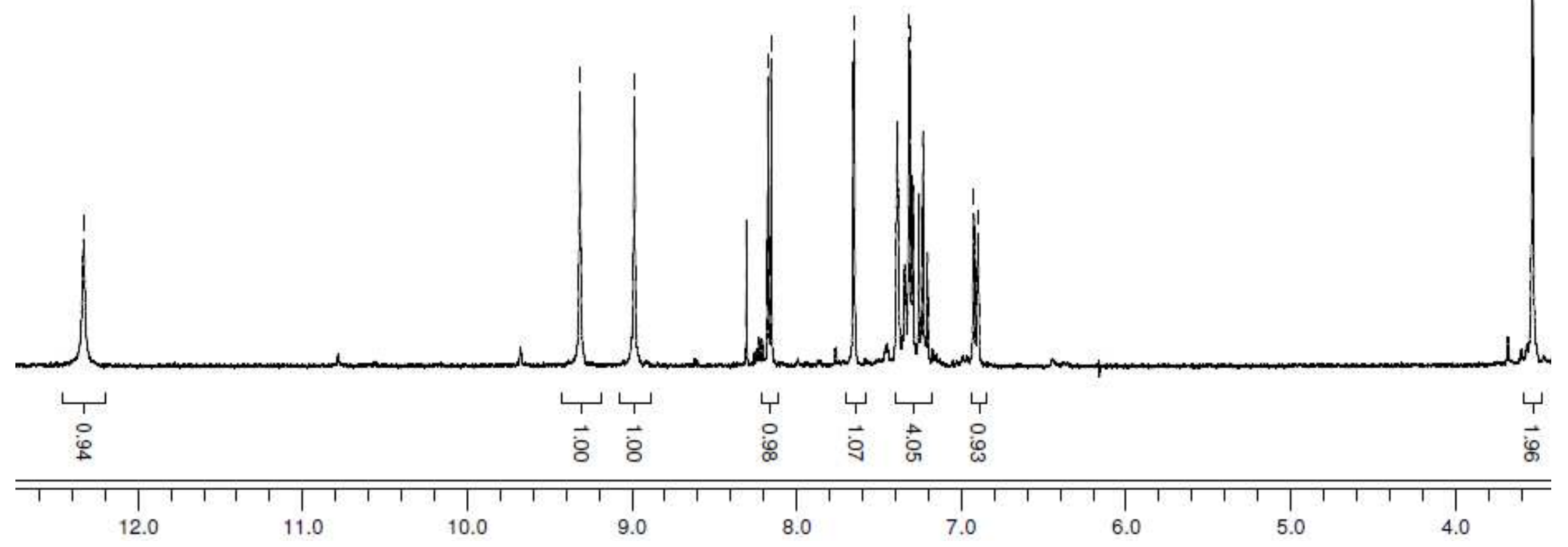

${ }^{1} \mathrm{H}$ NMR spectrum of 2-(3-(3-(2-chloropyridin-4-yl)ureido)acetic acid (4, hapten $\left.m 2\right)$ in DMSO-d 6 


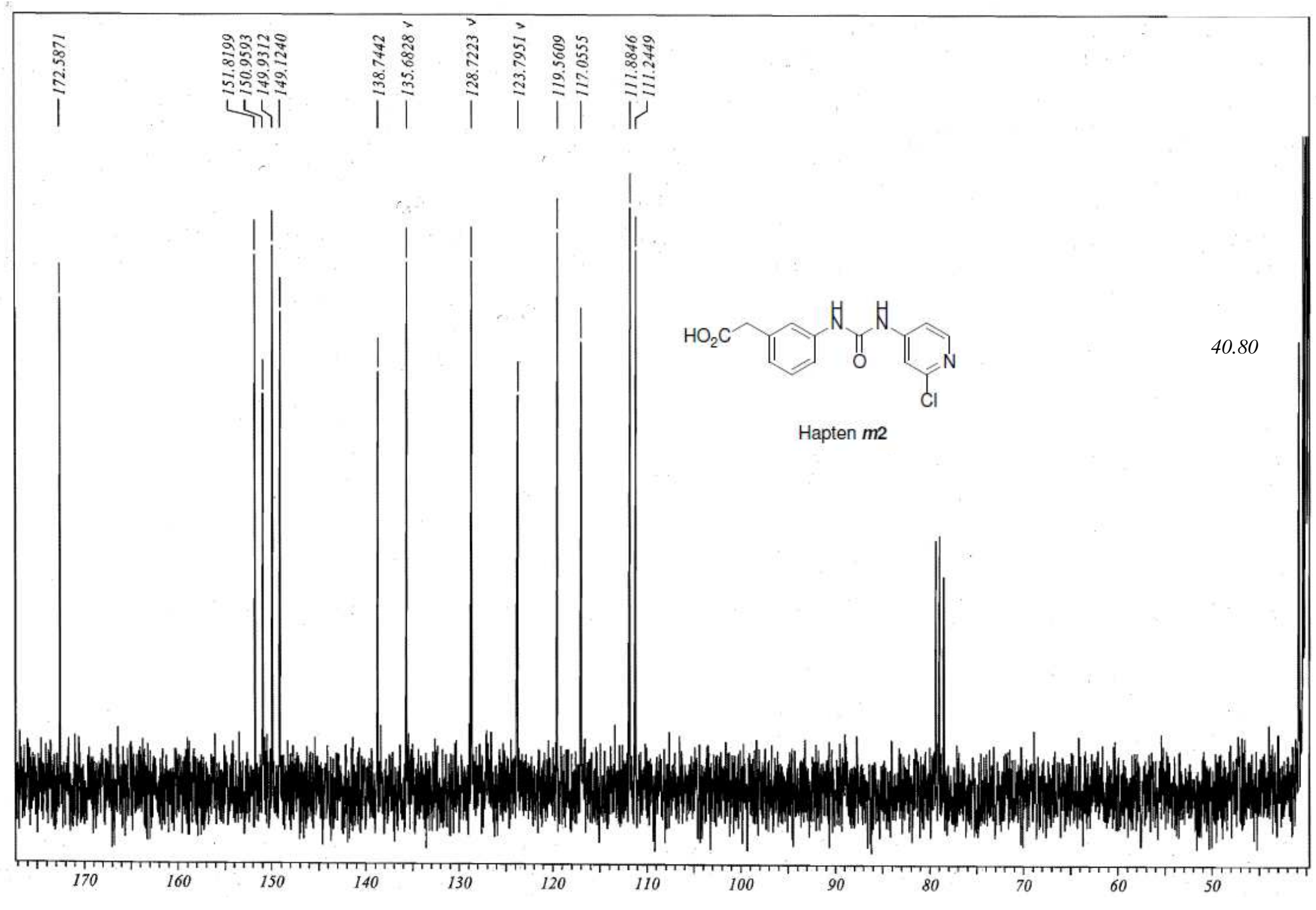

${ }^{13} \mathrm{C}$ NMR spectrum of 2-(3-(3-(2-chloropyridin-4-yl)ureido)phenyl)acetic acid (4, hapten $m 2$ ) in $\mathrm{CDCl}_{3} / \mathrm{DMSO}^{-\mathrm{d}_{6}}$ 


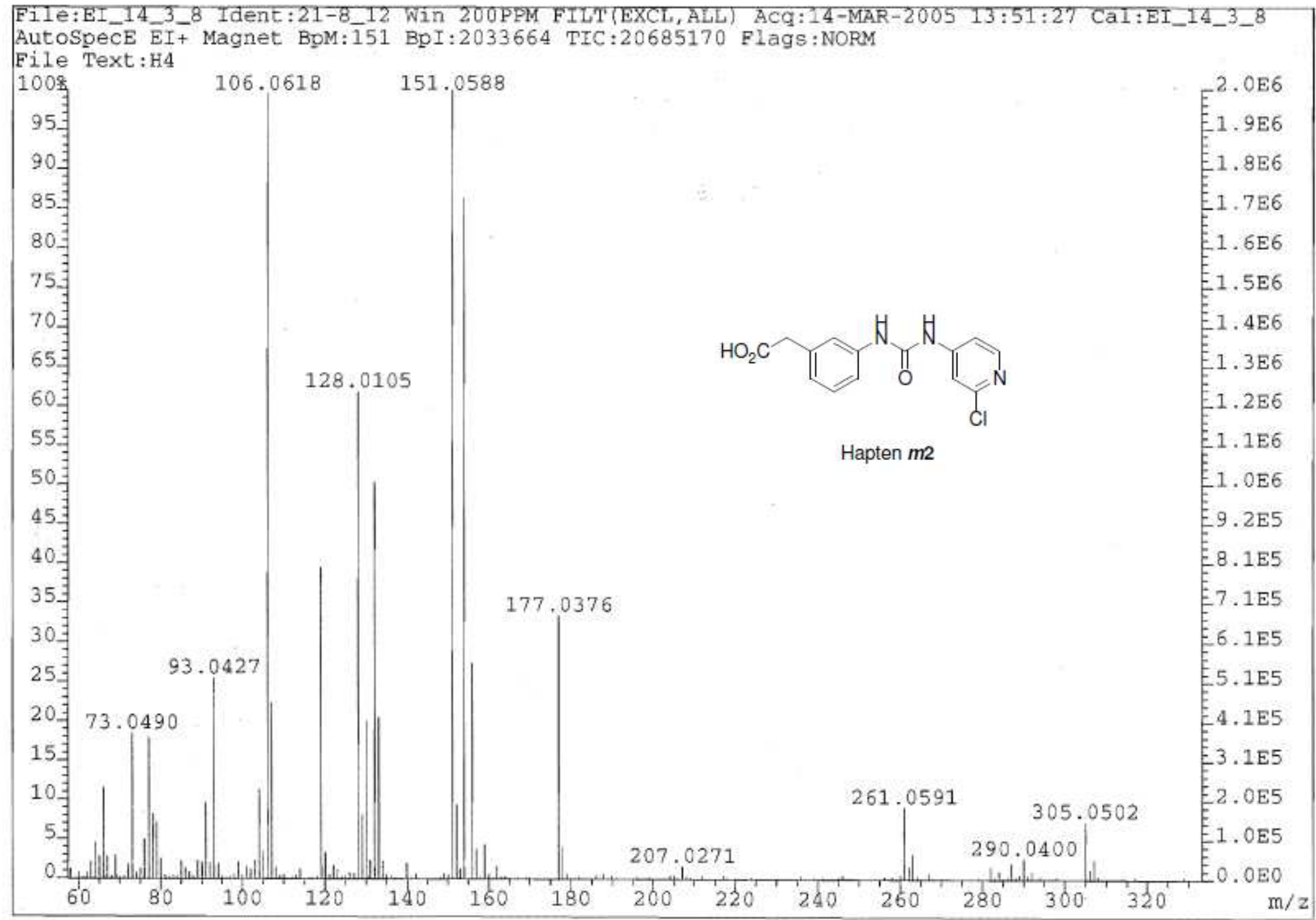

Mass spectrum of 2-(3-(3-(2-chloropyridin-4-yl)ureido)phenyl)acetic acid (4, hapten $m 2$ ) 


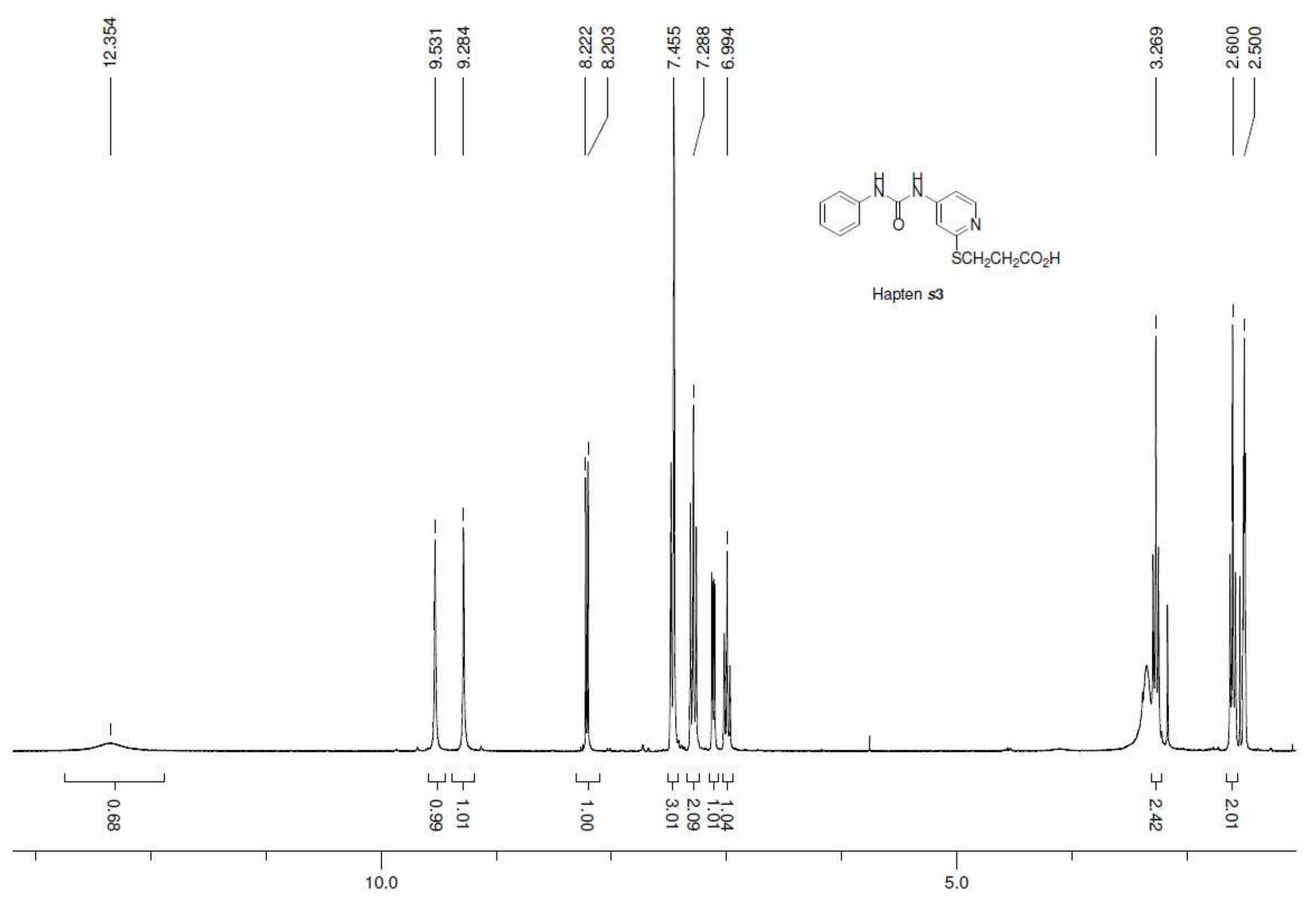

${ }^{1} \mathrm{H}$ NMR spectrum of 3-((4-(3-phenylureido)pyridin-2-yl)thio)propanoic acid (11, hapten $\left.s 3\right)$ in DMSO-d 6 
Organic \& Biomolecular Chemistry - For Review Only

Page 42 of 54
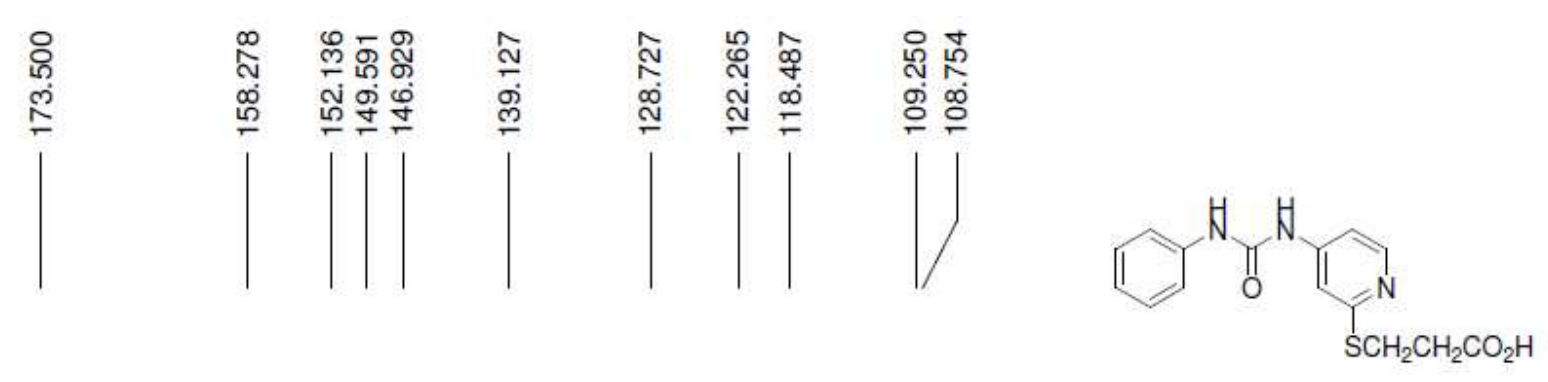

Hapten $s 3$
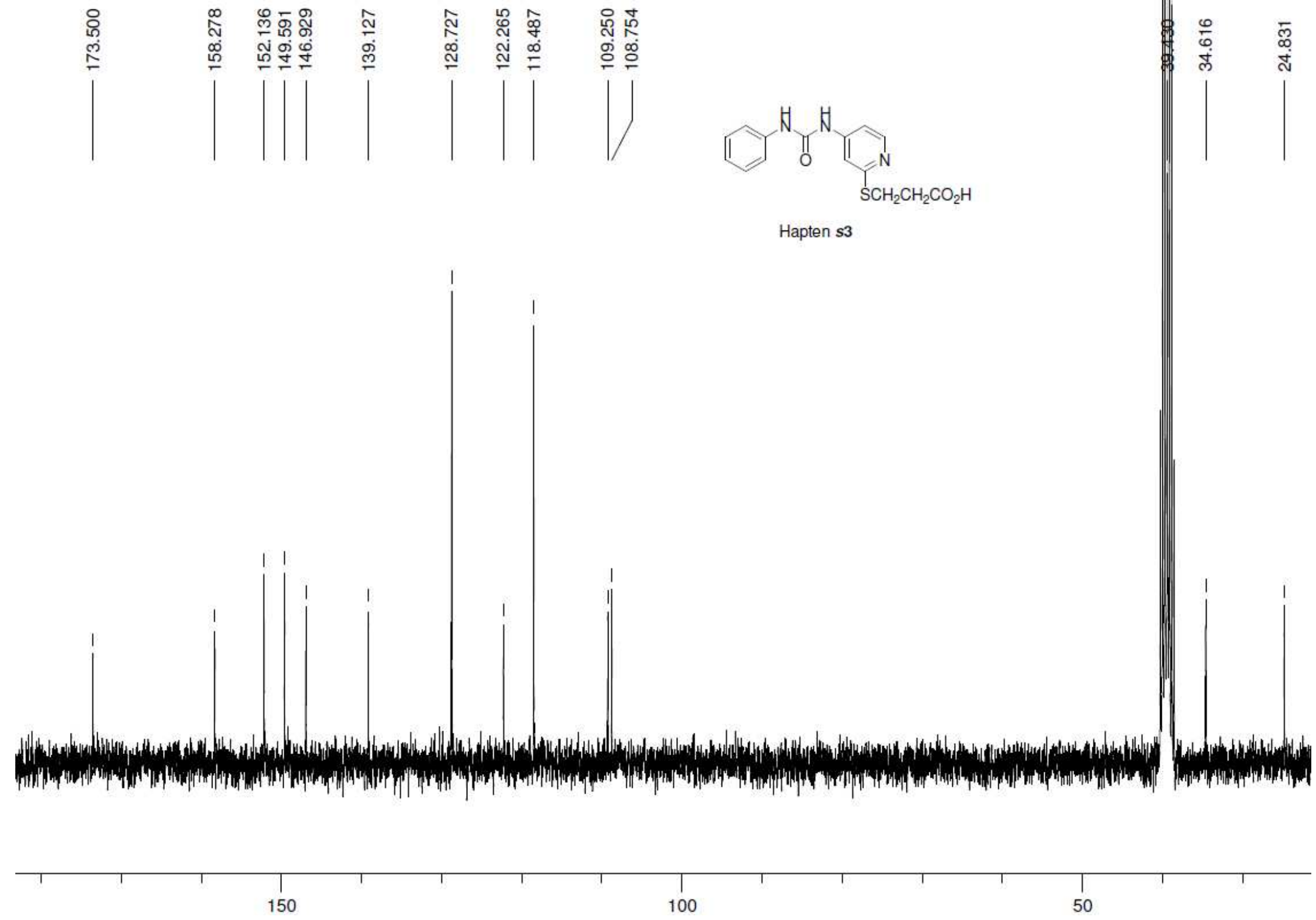

${ }^{13} \mathrm{C}$ NMR spectrum of 3-((4-(3-phenylureido)pyridin-2-yl)thio)propanoic acid (11, hapten $\left.s 3\right)$ in DMSO-d 6

ESI-20 


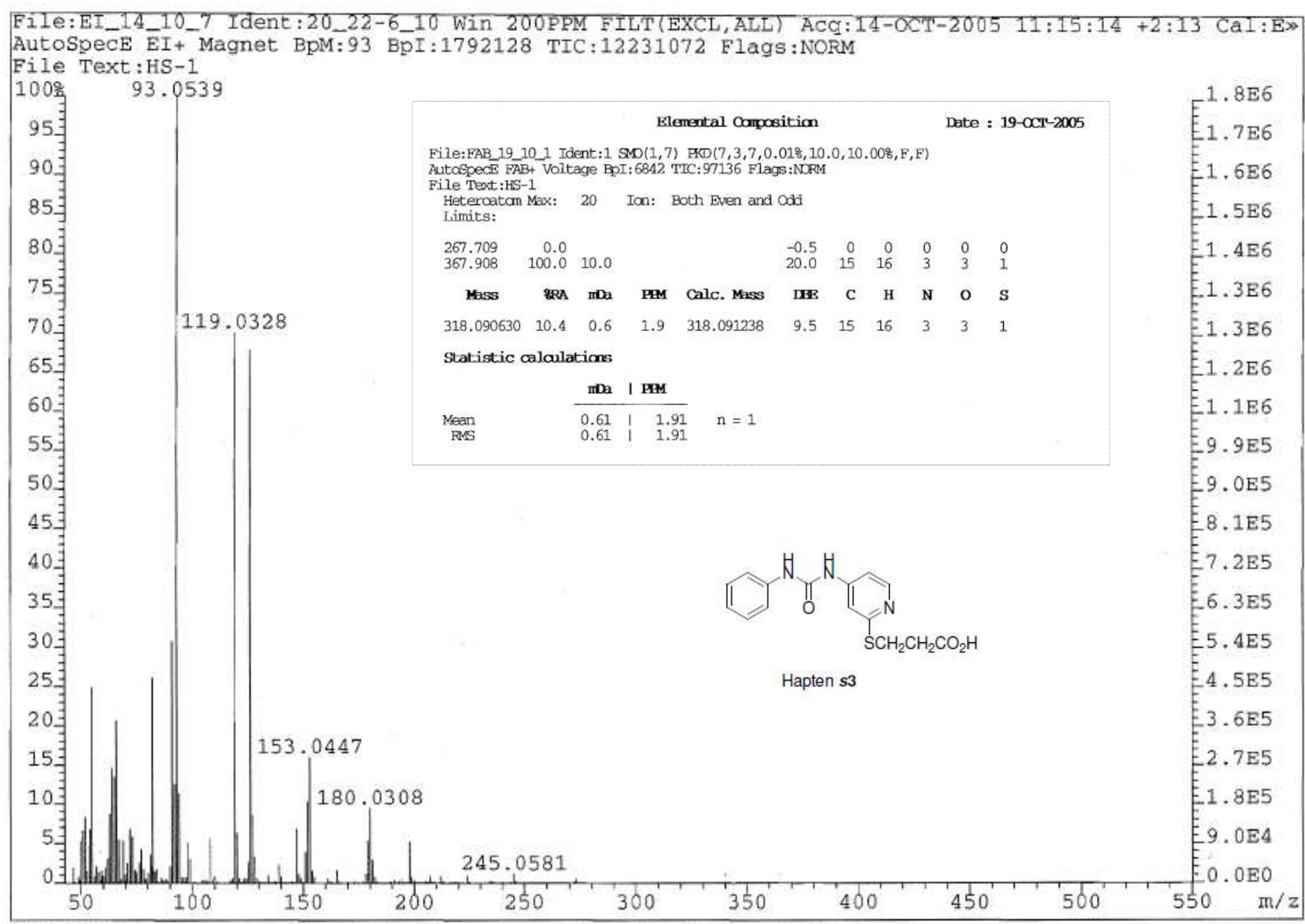

Mass spectrum of 3-((4-(3-phenylureido)pyridin-2-yl)thio)propanoic acid (11, hapten s3) 

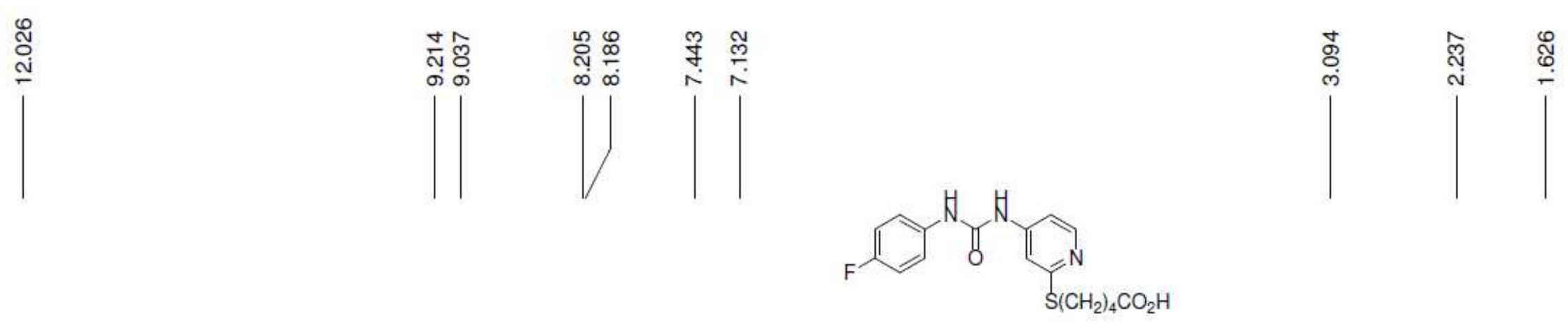

Hapten 4Fs5

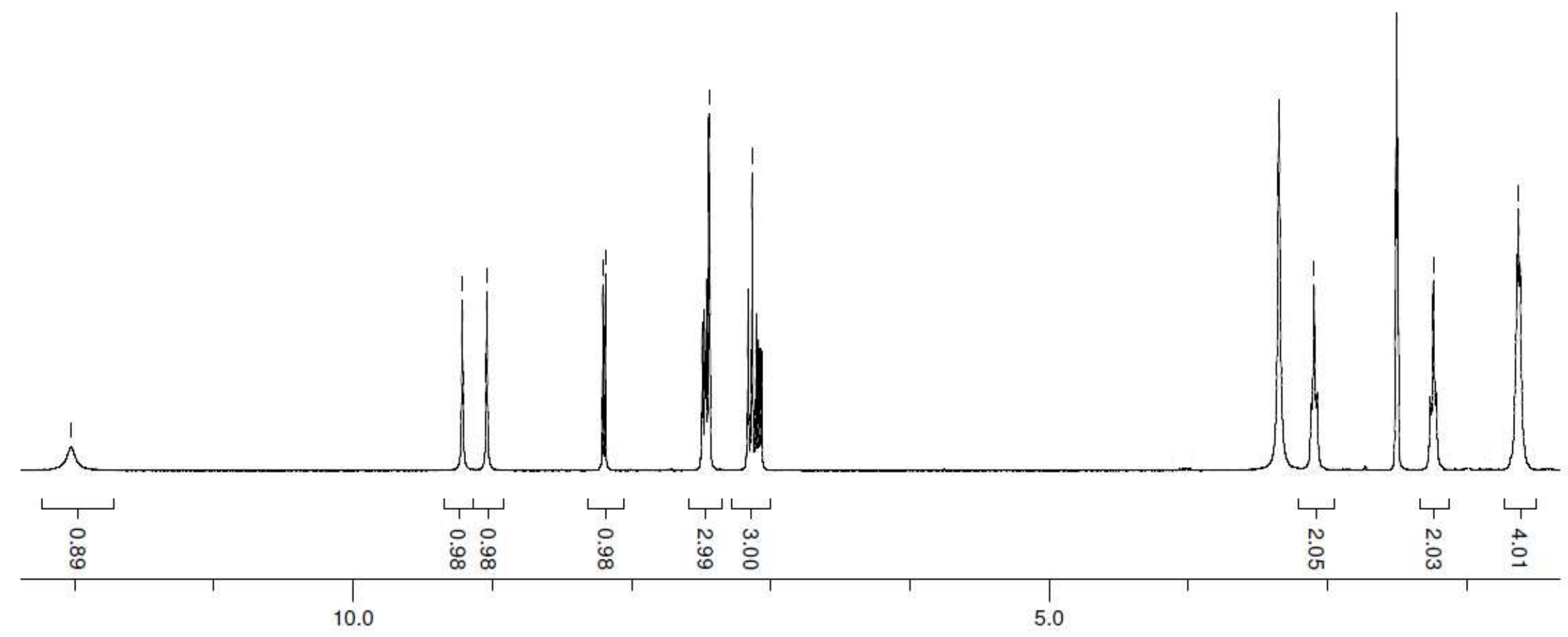

${ }^{1} \mathrm{H}$ NMR spectrum of 5-(4-(3-((4-fluorophenyl)ureido)pyridin-2-yl)thio)pentanoic acid (15, hapten 4Fs5) in DMSO-d 6 

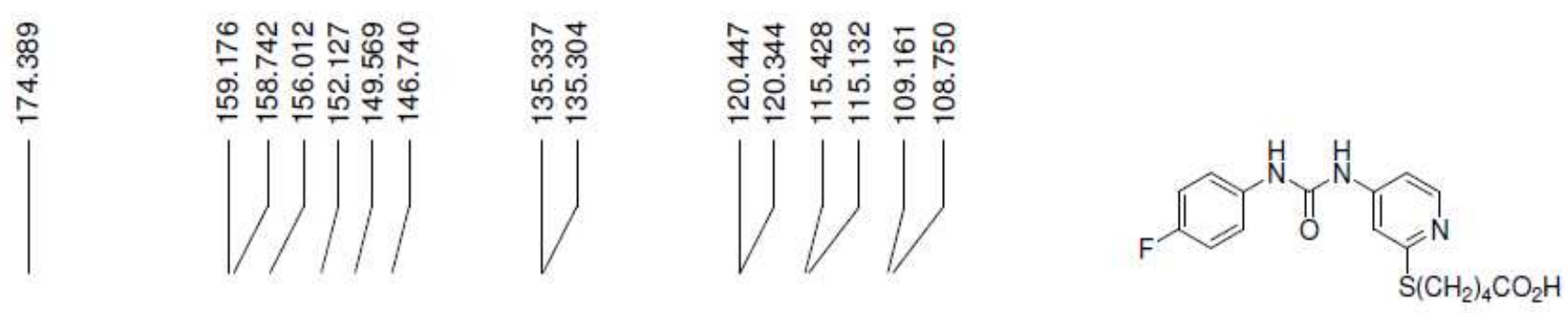

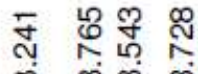

లె

Hapten 4Fs5

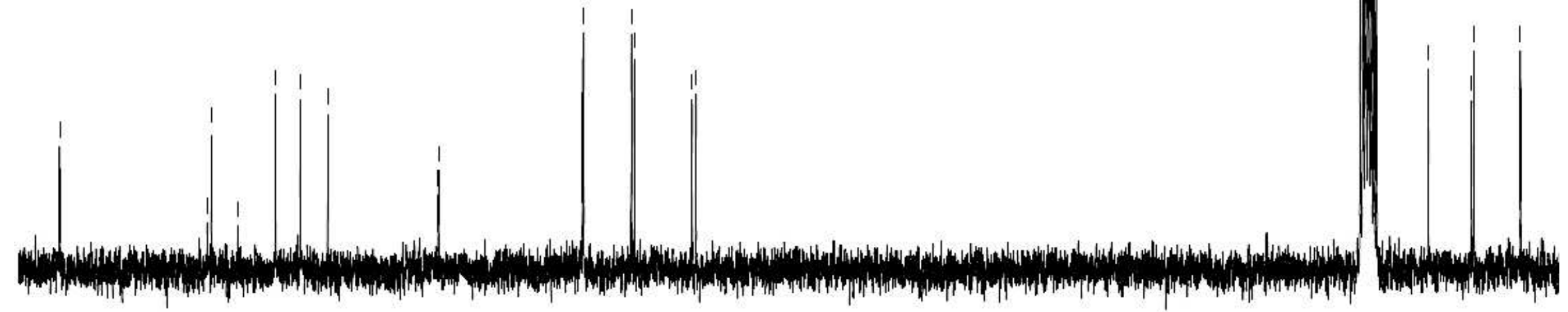

150

${ }^{13} \mathrm{C}$ NMR spectrum of 5-(4-(3-((4-fluorophenyl)ureido)pyridin-2-yl)thio)pentanoic acid (15, hapten 4Fs5) in DMSO-d 6 


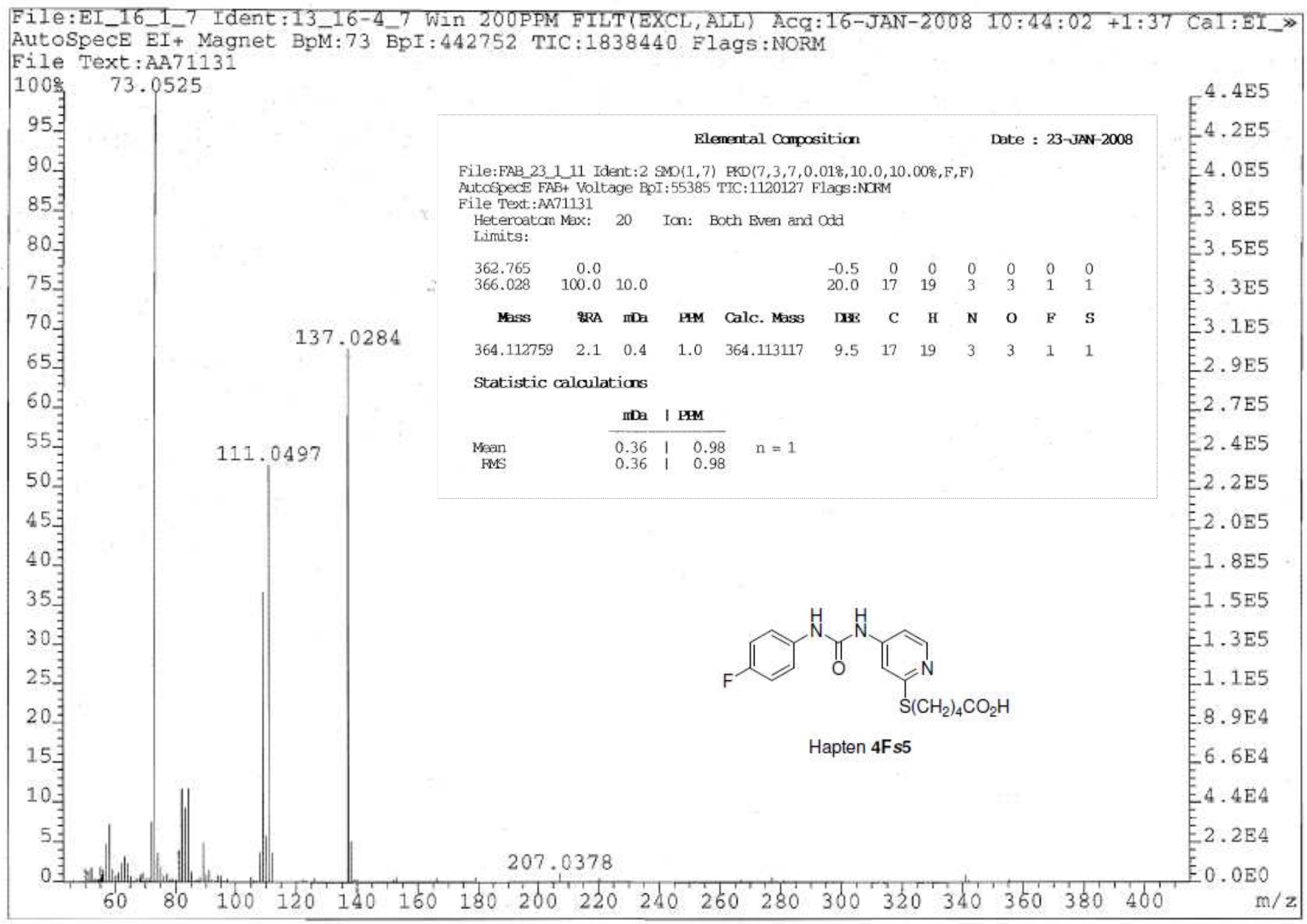

Mass spectrum of 5-(4-(3-((4-fluorophenyl)ureido)pyridin-2-yl)thio)pentanoic acid (15, hapten 4Fs5) 

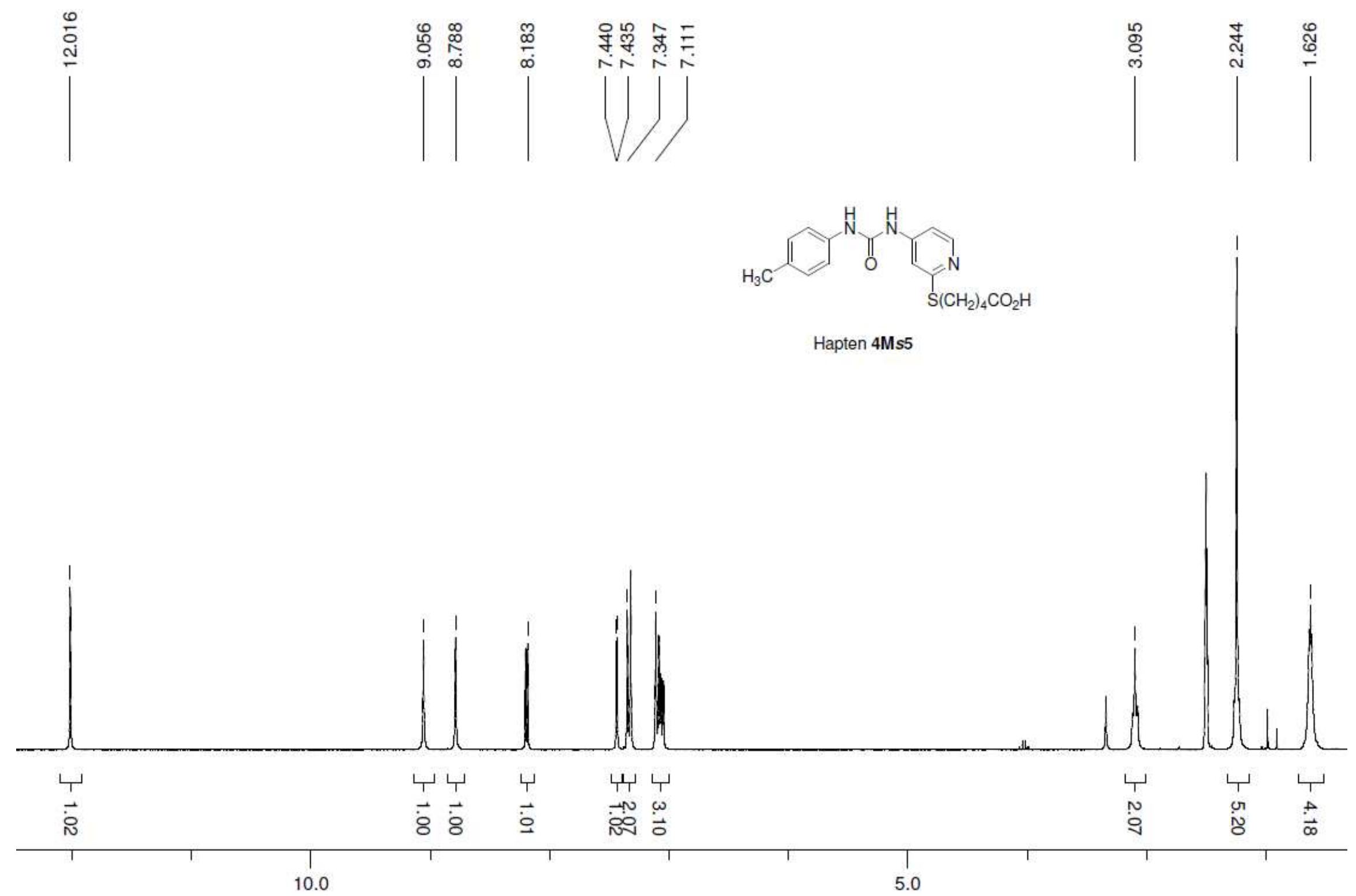

${ }^{1} \mathrm{H}$ NMR spectrum of 5-((4-(3-p-tolylureido)pyridin-2-yl)thio)pentanoic acid (18, hapten 4Ms5) in DMSO-d 6 


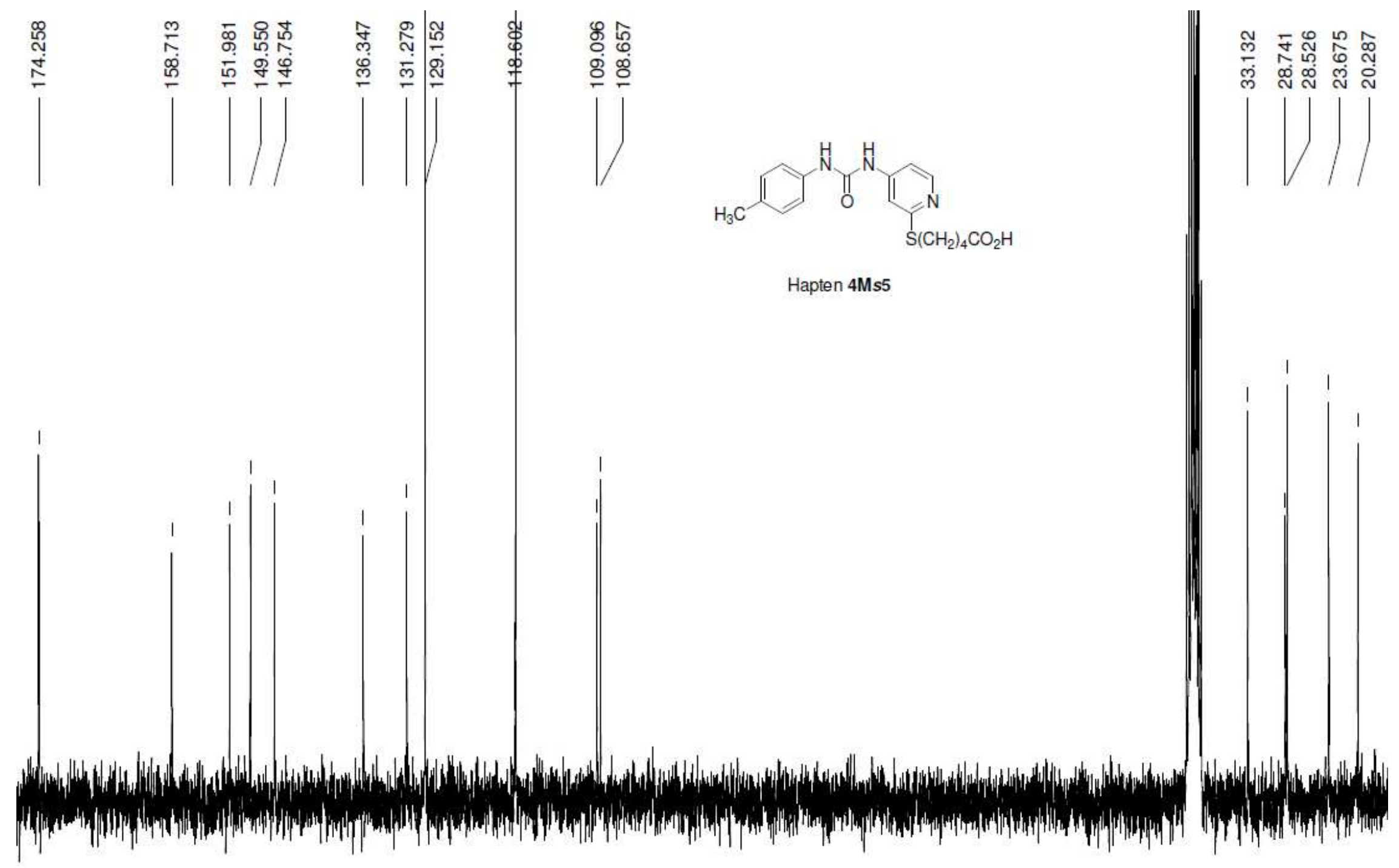

150

${ }^{13} \mathrm{C}$ NMR spectrum of 5-((4-(3-p-tolylureido)pyridin-2-yl)thio)pentanoic acid (18, hapten 4Ms5) in DMSO-d 6 


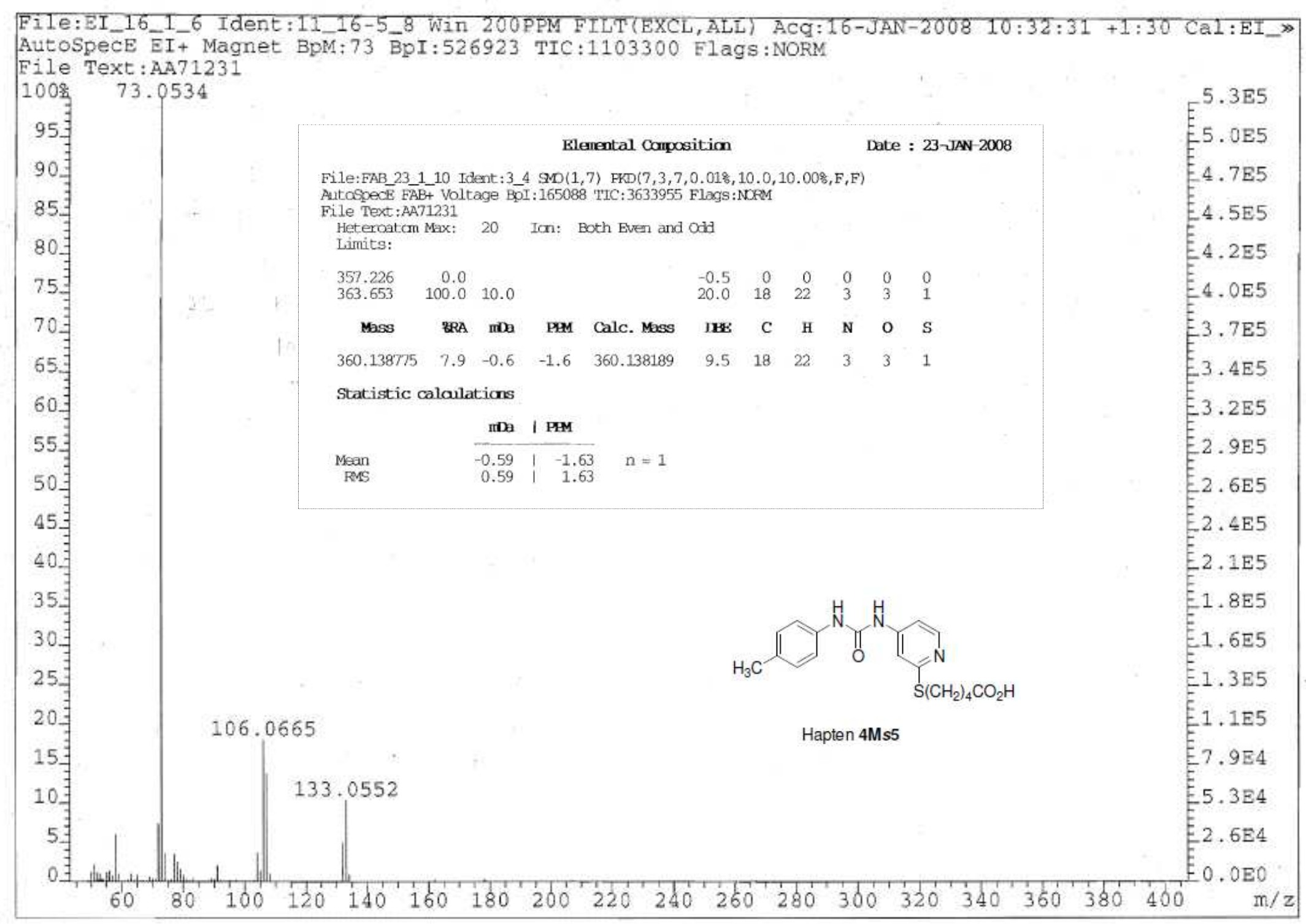

Mass spectrum 5-((4-(3-p-tolylureido)pyridin-2-yl)thio)pentanoic acid (18, hapten 4Ms5). 

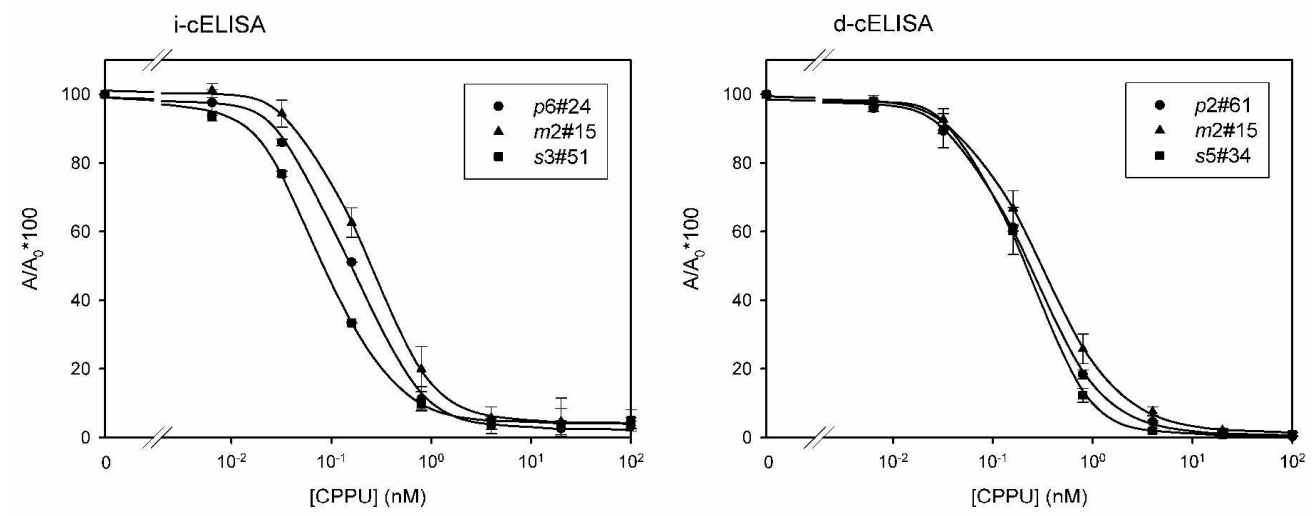

$310 \times 124 \mathrm{~mm}(600 \times 600 \mathrm{DPI})$ 


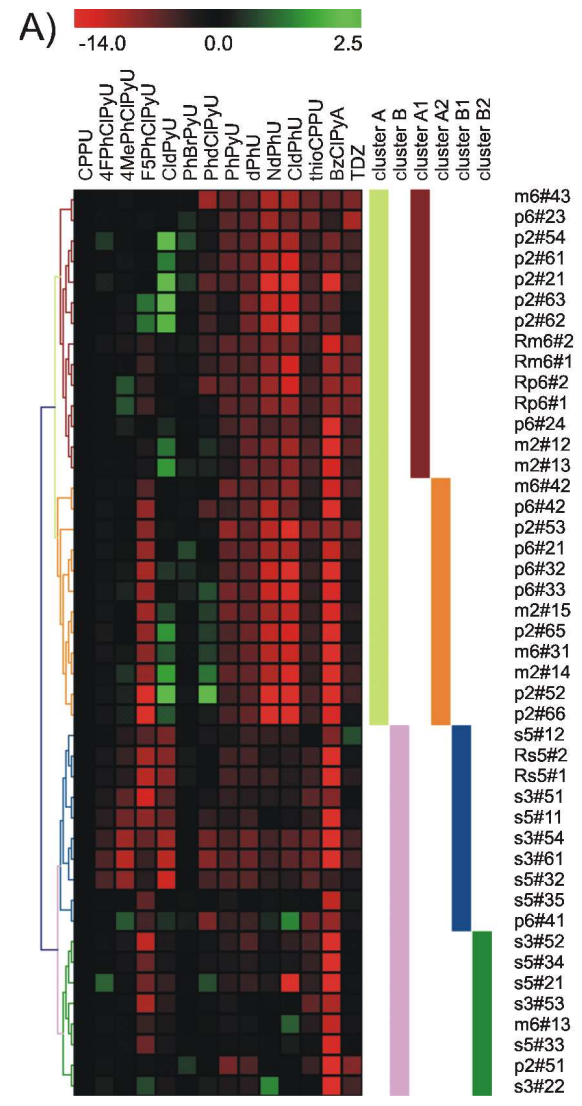

B)

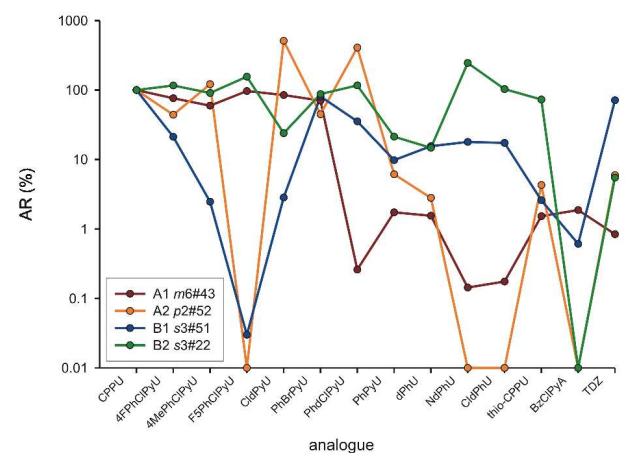

C)

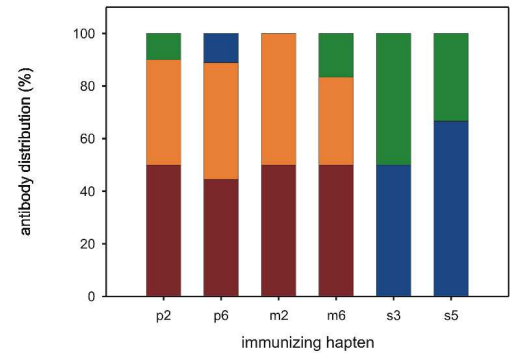




$\begin{array}{lll}0.0 & 0.35 & 0.7\end{array}$

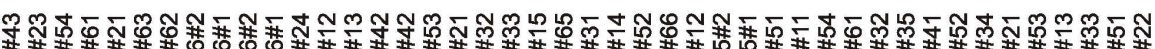

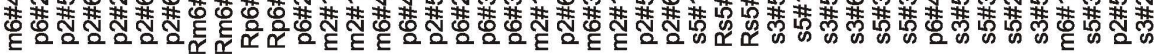

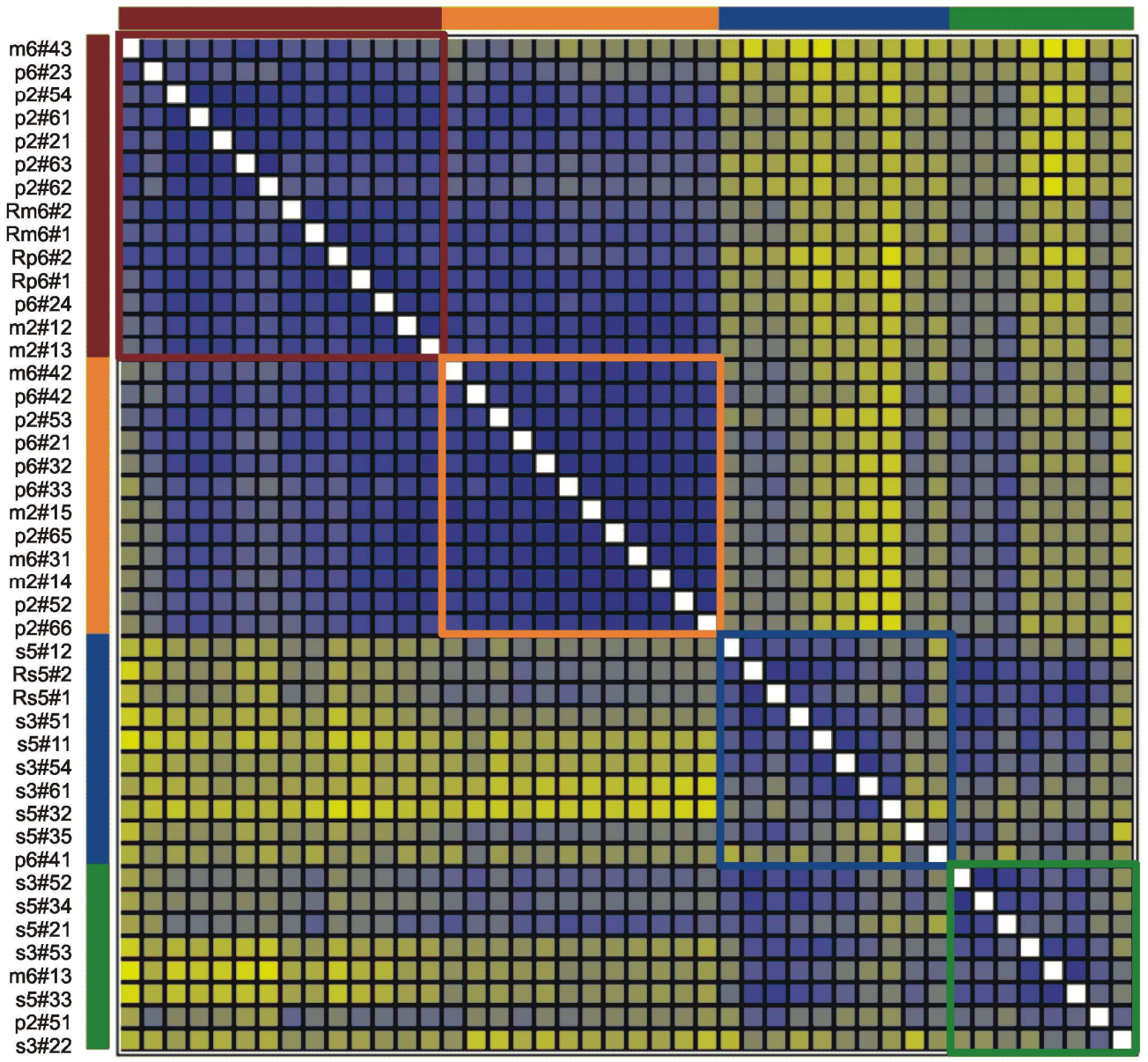

